\title{
Dediščina vojaških pokopališč, kapelic, spomenikov in spominskih znamenj prve svetovne vojne na Slovenskem
}

Vito HaZler

\section{UVOD}

$\mathrm{Na}$ Slovenskem smo se po drugi svetovni vojni rojene generacije dediščine prve svetovne vojne spominjale $\mathrm{v}$ veliki senci dogodkov in dosežkov delavskega gibanja in ljudske revolucije ter povojne socialistične družbene ureditve. Zgodovinski učbeniki so posebej izpostavljali sarajevski atentat in poznejše oblikovanje nenavadnih zavezništev znotraj centralnih in antantnih sil, ki so po končani vojni hitro razpadla, nastale pa so nove države in nova meddržavna razmerja.

Po drugi svetovni vojni rojene generacije so se $\mathrm{z}$ dediščino prve svetovne vojne srečevale večinoma $\mathrm{v}$ ozkih družinskih ali sosedskih krogih in skopo med šolskim izobraževanjem, saj je bilo zagotovo naporno pisati za vse sprejemljive zgodovinske učbenike o generaciji očetov nasprotnikov in za generacijo otrok sodržavljanov. Jugoslavija 
je bila že ob nastanku država nasprotij, ki so jo v začetku 1990-ih let pripeljala do razpada.

Naši sonarodnjaki so umirali $\mathrm{v}$ mnogih vojnah, na različnih straneh, doma in po svetu; za njihove grobove se mnogokrat niti ni vedelo. Šele z osamosvojitvijo Slovenije so te teme postopoma prihajale v ospredje. Številni članki potrjujejo, da so slovenski fantje pokopani v številnih evropskih pokrajinah, med drugim v poljski in ukrajinski Galiciji, na avstrijskem Koroškem in Tirolskem, globoko v zamejstvu Beneške Slovenije in Tržaške pokrajine, pa tudi na nekdanjih balkanskih bojnih črtah ob Drini in drugod. Večina jih tam za vedno počiva in nikoli se ne bodo vrnili. Zato so pomembna prizadevanja za ohranjanje spomina na padle rojake tudi v oddaljeni deželi Galiciji na Poljskem in v Ukrajini ter v nam sosednjih krajih v Italiji. Posebej pomembna pa so zlasti prizadevanja za ohranjanje fizičnih pričevanj prve svetovne vojne v Republiki Sloveniji, saj sodijo med najpomembnejše sestavine naše kulturne dediščine in so del slovenske kulturne identitete. Pozitiven odnos družbe do te vrste dediščine je bil v mednarodnih okvirih spodbujen že v začetku 1980-ih let in je odseval predvsem v kakovostnih obnovah najpomembnejših kulturnih spomenikov, kot je na primer Javorca nad Tolminom, pozneje pa ruska kapelica pod Vršičem in številni drugi spomeniki ali zgolj spominska znamenja v obliki nagrobnih ali stenskih plošč.

Opisane razmere so tudi na Slovenskem različne raziskovalne in varstvene ustanove ter posameznike spodbudile, da so svoje delo usmerili v problematiko prve svetovne vojne. $\mathrm{V}$ tej smeri je deloval tudi Oddelek za etnologijo in kulturno antropologijo Filozofske fakultete Univerze v Ljubljani, ki je skupaj z Narodopisnim inštitutom Slovenske akademije znanosti in umetnosti združil moči v skupen raziskovalni projekt Dedisčina prve svetovne vojne: reprezentacije in reinterpretacije. $S$ podporo tega projekta se je razvijalo tudi raziskovanje javnih spomenikov in znamenj, postavljenih v spomin padlim vojakom in drugim udeležencem prve svetovne vojne. Nabralo se je veliko različnega gradiva in različnih pogledov na obravnavano problematiko. Iz teh razmer je dozorela zamisel o konceptualno širši raziskovalni obravnavi.

Ta se v glavnem nanaša na tisti del kulturne dediščine prve svetovne vojne, ki je posledično povezan s končano življenjsko potjo številnih slovenskih vojakov in drugih udeležencev vojne predvsem na slovenskem ozemlju. Omenjene so tudi nekatere enote pokopališke in spominske dediščine $\mathrm{v}$ zamejstvu in nekaterih drugih evropskih krajih, a vendarle je glavnina navedb in opisov osredotočena na današnje slovensko ozemlje. Pri razvijanju raziskovalnega okvira gre 
velika zahvala vodji omenjenega raziskovalnega projekta, Božidarju Jezerniku, in Juriju Fikfaku, ki sta prispevala zamisli o dragoceni raziskovalni usmeritvi pričujočega besedila ter vrsto pomembnih podatkov in slikovnega gradiva. ${ }^{\mathbf{1}}$

V raziskavi je bilo doslej mogoče zbrati podatke o skupno $459^{2}$ vidnih in dokumentiranih lokacijah, in sicer o 94 vojaških pokopališčih in grobiščih, o 276 posameznih spomenikih in znamenjih, posvečenih padlim vojakom, zdravstvenemu osebju in drugim udeležencem vojne, o 32 spomenikih, posvečenih znanim osebnostim, ter o 56 kapelicah in kapelah in o eni mošeji, ki so jih še med vojno postavljali vojaki v bližini fronte in na nekaterih vojaških pokopališčih ali pa svojci doma $\mathrm{v}$ spomin na padle sorodnike, pa tudi srečneži, ki so se zdravi ali invalidi s številnih evropskih front vrnili domov. Ob tem je treba spomniti na številna vojaška pokopališča izven meja Republike Slovenije, kjer so bodisi na zavezniških ali na pokopališčih nasprotnikov pokopani številni slovenski vojaki. Takšna so grobišča in pokopališča na Debeli griži (Monte San Michele), v Doberdobu (Doberdò), Foljanu (Fogliano), Nabrežini (Nabresina) in Proseku (Prosécco) ter velike kostnice v Sredipolju (Redipuglia) in Oslavju (Oslavia) v Italiji, pa tudi pokopališča v poljskem mestu Gorlice in ukrajinskem Lvovu, kjer so na območju nekdanje Galicije umirali slovenski vojaki, ki jim je naša država šele leta 2018 postavila dostojne spomenike.

$\mathrm{Na}$ današnjem slovenskem ozemlju ima največ zaslug za postavitev spomenikov in znamenj padlim in pogrešanim vojakom v prvi svetovni vojni predvsem Združenje bojevnikov z neutrudnim nekdanjim vojaškim kuratom Francem Bonačem, ki si je z Jernejem Hafnerjem in Ivanom Matičičem prizadeval za postavitev javnih spomenikov in znamenj. Bonač in Hafner sta v več člankih v časopisih in časnikih kritično ocenjevala brezbrižnost javnosti in nekdanjih sobojevnikov do ohranjanja spominov na padle in pogrešane vojake. Zlasti Bonač je

Slikovno gradivo in pisne vire so prispevali tudi drugi, med njimi Tomaž Majcen, geolog in strokovni sodelavec Muzeja Laško. Na Jesenicah je tamkajšnjo kostnico fotografirala etnologinja Mojca Bele, dragoceno slikovno gradivo iz družinske fototeke o spomenikih prve svetovne vojne pa je prispeval Janez Bogataj. Prav te fotografije so omogočile primerjalno analizo in opozorile na velik problem razvrednotenja javnih spomenikov, ki z vsakokratno obnovo (beri: prenovo) izgubljajo svoje prvobitne spomeniške vrednosti.

2 Ocenjujemo, da je skupno število obravnavanih enot dediščine prve svetovne vojne večje. Zadnje raziskave na Kočevskem (Anja Moric, v tej knjigi) nakazujejo obstoj vsaj še treh spomenikov oziroma znamenj, ki so propadli ali bili uničeni po odselitvi večine Kočevskih Nemcev leta 1942. Od domnevno skupno desetih enot spomenikov in znamenj so danes ohranjene le še tri: spominska plošča na zunanjščini župnijske cerkve v Stari Cerkvi (občina Kočevje), Mihljov križ ob cesti v Mirtovičih (občina Osilnica) in kapelica v vasi Seč (občina Semič). 
izpostavljal zglede iz evropskih držav in si skupaj z nekdanjimi bojnimi tovariši prizadeval za društveno organizacijo Zveza bojevnikov in obenem pri javnosti za večjo pripravljenost pri postavljanju spomenikov. Zvezi bojevnikov je uspelo zainteresirati javnost, tako da je bilo v različnih krajih postavljenih okrog 150 spomenikov in znamenj. Člani Zveze bojevnikov so se vsako leto konec avgusta udeleževali shodov na Brezjah (Jezernik 2014: 341). V spomin na vojne dogodke so 31. avgusta 1924 v notranjščini romarske cerkve Marije Pomagaj vgradili spominsko znamenje (Jezernik 2014: 342).

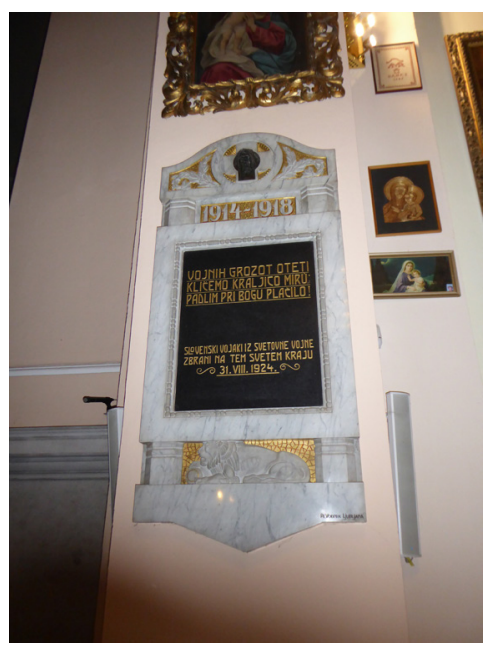

Slika 1: Brezje, romarska cerkev Marija Pomagaj. Znamenje v spomin na veliki shod Zveze bojevnikov, ki je prvič potekal 31. avgusta 1924 (foto: Vito Hazler, 13. 1. 2019).

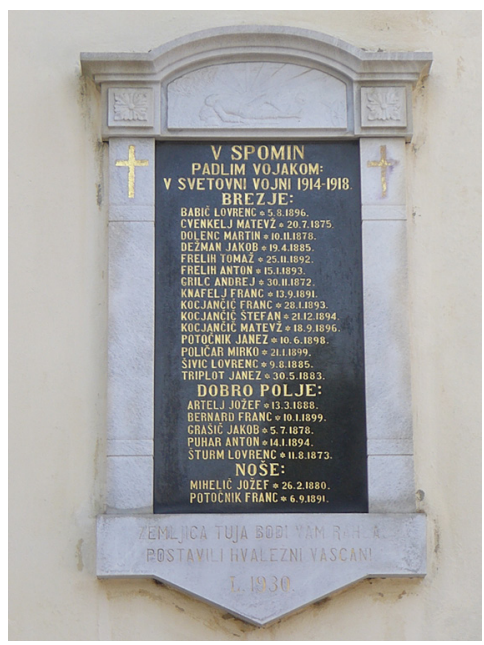

Slika 2: Brezje, znamenje iz leta 1930 na zunanjščini romarske cerkve Marija Pomagaj, vgrajeno $\mathrm{v}$ spomin padlim vojakom $\mathrm{v}$ prvi svetovni vojni iz vasi Brezje, Dobro Polje in Noše (foto: Vito Hazler, 15. 1. 2019).

Spominske plošče so v letih po prvi svetovni vojni vgrajevali tudi na pročelja različnih kapel. Za vgraditev so izbirali pročelno stran (Luže v občini Šenčur, kapela sredi križišča), notranjost pod menzo (Šentjošt nad Horjulom) in tudi spodnji del zadnje zunanje stene kapele, ki je prislonjena ob pokopališki zid (Zgornji Razbor, kapela $s$ Križanim v niši in spominsko ploščo padlim vojakom v prvi svetovni vojni na njeni hrbtni strani, ki je obrnjena proti pokopališču župnijske cerkve sv. Danijela).

Predvsem spominske plošče so v več krajih postavljali še v letih po osamosvojitvi Slovenije ter ob stoletnicah začetka in konca prve svetovne vojne. Takrat so odkrili spominske plošče v Bovcu v spomin na vse trpeče v prvi svetovni vojni (21. maja 2018), v Železnikih so spominsko ploščo vgradili devet dni pred stoletnico konca vojne na 


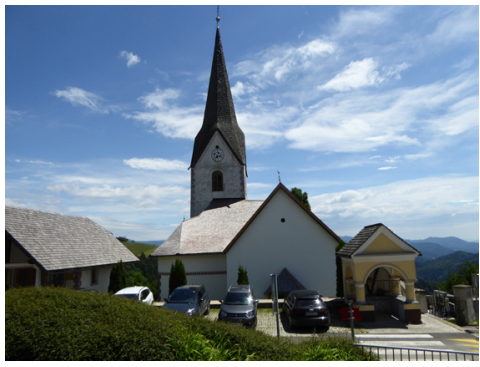

Slika 3: Zgornji Razbor, kapela s kipom Križanega v niši, za njo pokopališča in župnijska cerkev sv. Danijela, spominska plošča padlim v 1. svetovni vojni (foto: Vito Hazler, 22. junija 2020).

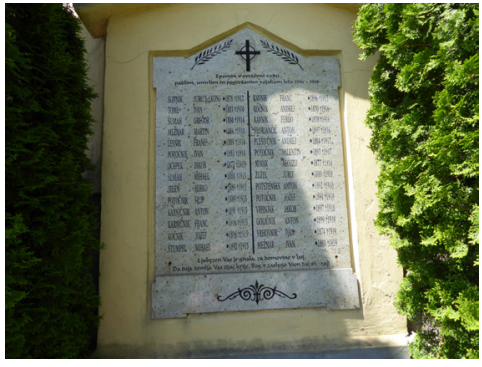

Slika 4: Zgornji Razbor. V pokopališki zid in zadnjo steno pod kapelo $s$ kipom Križanega je vzidana spominska plošča padlim domačinom - vojakom v prvi svetovni vojni. $\mathrm{Na}$ plošči iz svetlo sivega kamna je vklesanih 28 imen vojakov, leto njihovega rojstva in smrti (foto: Vito Hazler, 22. junija 2020).

zunanjščino cerkve sv. Frančiška Ksaverija, v Šentrupertu na cerkvi sv. Ruperta in na Vrhniki pod cerkvijo Svete Trojice pa 11. novembra 2018 ob 11. uri in 11. minut, ko je bila stoletnica uradnega konca prve svetovne vojne) in drugod.

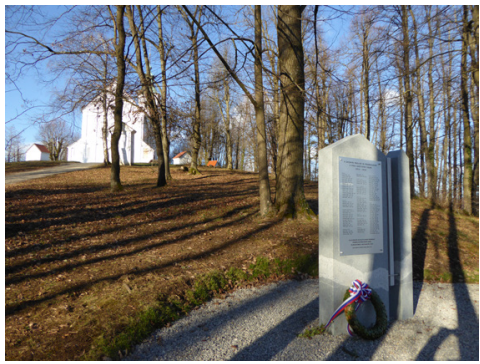

Slika 5: Vrhnika. Grič vzhodno pod cerkvijo sv. Trojice, spomenik padlim v prvi svetovni vojni, odkrit 11.11. 2018 ob 11. uri (foto: Vito Hazler, 3. 1. 2019).

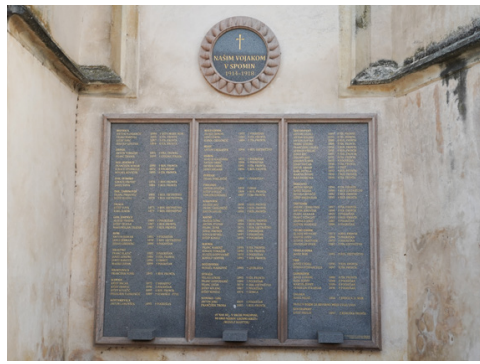

Slika 6: Šentrupert na Dolenjskem. Na južni zunanji steni prezbiterija župnijske cerkve sv. Ruperta so 11.11. 2014, ob 11. uri, svečano odkrili spominsko ploščo padlim domačinom, vojakom v prvi svetovni vojni (foto: Alenka Stražišar Lamovšek, 14.9.2020).

Raziskovanje vojaških pokopališč, kapelic, spomenikov in spominskih znamenj prve svetovne vojne je temeljilo na zbiranju in proučevanju dosegljivih pisnih in slikovnih virov ter literature, na terenskem delu 
po Sloveniji in v nekaterih obmejnih krajih v Italiji in Avstriji, predvsem pa na večkratnem preverjanju in zbiranju gradiva $\mathrm{v}$ različnih varstvenih, raziskovalnih in pedagoških ustanovah, kot so Arhiv Slovenije, Zgodovinski arhiv Celje, Muzej Laško, Muzejska zbirka Predjama, Slovenski etnografski muzej ter Oddelek za etnologijo in kulturno antropologijo Filozofske fakultete Univerze v Ljubljani. Veliko podatkov so posredovali tudi ljudje na terenu z območja Spodnje Savinjske doline, Goriškega, Tolminskega, Bovškega, Trente, Bohinja, Poljanske doline, Škofje Loke, Kranja, Tržiča, Kamnika in od drugod.

Raziskava je potekala ob sprotnem dopolnjevanju in preverjanju pisnih in slikovnih virov tudi po spletnih straneh, ki so jih ob različnih priložnostih in z različnimi nameni objavljali večinoma nepodpisani avtorji, pa tudi avtorji z imeni in priimki. Med njimi so posebej dragoceni in strokovno zanesljivi zapisi Draga Svoljšaka in Damirja Globočnika. Zelo uporabni in preverjeno verodostojni so bili podatki o vojaških pokopališčih na Krasu, Goriškem, Tolminskem, Bovškem in v Trenti, ki so jih na spletnih straneh objavili številni anonimni pisci. Posebna zahvala velja Mariji Rančigaj iz Gomilskega za podatke o gradnji spomenika padlih vojakov - domačinov - v Grajski vasi v Spodnji Savinjski dolini ter Miri Bandelj za terensko delo po italijanskih in avstro-ogrskih pokopališčih ter med spomeniki na Krasu, Goriškem, Banjšicah, Tolminskem, Bovškem in v Trenti.

Kot zelo uporabna so se izkazala zlasti tiskana besedila v obliki člankov in monografij. Spomenike, posvečene padlim v prvi svetovni vojni, je med prvimi na Slovenskem z umetnostnozgodovinskega zornega kota obravnavala Špelca Čopič, ki je med letoma 1958 in 1986 raziskovala opus kiparja Lojzeta Dolinarja (Čopič 1958: 841-46; 1985; 1986: 87-100), med drugim avtorja spomenika padlim vojakom v prvi svetovni vojni na Polzeli (1927). Čopičeva je v članku Slovenski spomeniki padlim v prvi svetovni vojni (Čopič 1987: 168-77) prva na Slovenskem pregledno predstavila javne spomenike in njihove avtorje, ki so v času med svetovnima vojnama ustvarili več vidnih spomenikov. Ta članek je pomembno vplival tudi na razširitev delovnega področja spomeniškovarstvene službe in okrepil zavest javnosti o (do takrat) močno spregledanem žanru različnih javnih spomenikov.

Strokovno odmevna so bila tudi poročila v reviji Varstvo spomenikov, ki so po letu 1980 navajala vse številčnejše podatke o poteku in obsegu obnov spomenikov prve svetovne vojne. Pri tem so se izkazali zlasti konservatorji Zavoda za varstvo naravne in kulturne dediščine Nova Gorica, ki so poročali o vidnih dosežkih obnov, na primer na Javorci nad Tolminom (Smole 1982: 235), o restavriranju spomenika padlim v prvi svetovni vojni v Moravčah (Benedik 1984: 333), o vojaškem 
pokopališču iz prve svetovne vojne v Batah (Humar 1985: 354), o spomeniku pod vodnim zbiralnikom v Grgarskih Ravnah (Humar 1986: 343), o italijanskem spomeniku na nekdanjem vojaškem pokopališču nad Avčami pri Kanalu (Humar 1998: 10) in o drugih dosežkih stroke.

Leta 1996 je Marko Simič, zgodovinar in konservator Zavoda za varstvo kulturne dediščine RS, objavil odmevno knjigo Po sledeh soške fronte, $\mathrm{v}$ kateri je obravnaval bistvene poteze večkratnih ofenziv ter uspehe in poraze bojujočih se strani, med drugim avstrijskega 6 . domobranskega pehotnega polka, ${ }^{3} \mathrm{ki}$ se je bojeval proti italijanski elitni enoti arditi $^{4}$ na strateško pomembnem Škabrijelu, $646 \mathrm{~m}$ visokem hribu nad Novo Gorico, Solkanom in Grgarsko kotlino. Obe vojskujoči se strani sta na tem bojišču v enajsti soški bitki izgubili veliko vojakov.

$\mathrm{V}$ avstro-ogrsko in italijansko vojsko so bili vpoklicani fantje in možje večinoma med osemnajstim in petdesetim letom starosti. Znani so tudi primeri še mlajših nabornikov, ki so padli kmalu po vpoklicu, ${ }^{\mathbf{5}}$ in starejših izkušenih vojakov, ki so krepko prekoračili petdeseto leto. Nekateri med njimi so padli le nekaj mesecev ${ }^{6}$ pred koncem vojne. Prav te življenjske zgodbe in usode vojakov je med drugimi avtorji obravnavala Nataša Budna-Kodrič v knjigi Vojaki s Škofjeloškega v prvi svetovni vojni. O Škofji Loki kot globokem zaledju soške fronte je objavljenih še več drugih spisov, na primer o vojaški bolnišnici v uršulinskem samostanu (Podlipnik 2015), pa tudi o Jurkovičevem spomeniku žalujoče Slovenke, ki so ga leta 1928 postavili sredi nekdanjega loškega pokopališča (glej Božidar Jezernik, v tej knjigi), in o spomeniku padlim vojakom ob župnijski cerkvi sv. Jurija v Stari Loki iz leta 1930, delo kiparja Boža Pengova. ${ }^{7}$

$\mathrm{Za}$ razumevanje vojnih razmer in dogajanja po prvi svetovni vojni so pomembni še drugi pisni viri, med katerimi velja izpostaviti nekaj najbolj pričevalnih in za raziskovalce dovolj uporabnih. David Erik Pivec je pisal o spomeniku hrabrih branilcev Rombona (2003), o soški fronti kot pomniku in muzejskem vprašanju se je $\mathrm{v}$ diplomskem delu razpisal Damjan Resnik (2004), o mošeji v Logu pod Mangartom pa je med drugimi pisal Vinko Avsenak (2006: 45-50).

Za razumevanje življenja $\mathrm{v}$ frontnem zaledju ter življenjskih zgodb vojakov med vojno in še posebej v času vojaških dopustov je

3

Izvirno nemško: Kaiser und König Landwehr Infanterie Regiment »Eger« Nr. 6 . Arditi je bilo ime specialnega korpusa Kraljeve italijanske kopenske vojske, ki so ga ustanovili leta 1917.

Npr. Tomaž Marinčič iz Dragomera št. 15 je padel pri sedemnajstih letih (glej Brezovica pri Ljubljani, spomenik padlim v prvi svetovni vojni).

Npr. Lovro Kušar iz Notranjih Goric št. 21 je padel pri dvainpetdesetih letih (glej Brezovica pri Ljubljani, spomenik padlim v prvi svetovni vojni).

Spomenik padlim v prvi svetovni vojni (spletni vir: http://spomeniki.blogspot. com/2017/08/stara-loka-spomenik-padlim-v-prvi.html, prevzeto 17. 10. 2018). 
pomemben vir monografija več avtorjev Dediščina župnije Šentjošt: Ljudje, domačije in znamenitosti (Košir idr. 2013), ki med drugim predstavlja vojake na nekajdnevnem dopustu, ko so si vzeli čas tudi za fotografiranje z ženo v fotografskem ateljeju v Ljubljani in na Vrhniki. Posebej zanimivi so otopeli obrazi fotografiranih vojakov, ki se kljub nekajdnevnemu civilnemu življenju očitno niso otresli spominov na grozote vojne, zato se njihove oči zdijo brezosebne in stekleno hladne.

Število strokovnih in poljudnih člankov in monografij se je občutno povečalo $\mathrm{v}$ letih pred spominjanjem stoletnice začetka in konca prve svetovne vojne. Ponekod so se spominjali žrtev (Prašnički idr. 2013) ter usode mož in fantov v svetovni vojni (Prašnički 2014), drugod v Julijskih Alpah so dokumentirali ohranjene sledi vojnih dogodkov (Turk 2013: 29-31) idr. Posebej pomembne so večtematske obravnave vojne in vojnega zaledja, ki so jih napisali strokovnjaki iz več slovenskih arhivov in muzejev. Svoje raziskovalne dosežke so predstavili v pregledni razstavi in na spletnih straneh pod skupnim naslovom $V$ zaledju soske fronte (Eržen Podlipnik idr. 2015). V tem tematskem pregledu je objavljenega veliko slikovnega gradiva, načrtov in izvirnih (faksimiliranih) besedil. Za našo rabo so pomembni zlasti prispevki Bombardiranje civilnih objektov (Barbara Pešak Mikec), Skrb za begunce (Teja Krašovec), Vojni ujetniki (Barbara Žabota), Iz ognjenega pekla $v$ zavetje bolnišnic (Judita Šega), Za bolnišničnimi zidovi (Judita Šega) ter Za sprostitev in zabavo (Elizabeta Eržen Podlipnik). ${ }^{\mathbf{8}}$

Zanimivo je, da je prva svetovna vojna v letih spominjanja 100-letnice njenega začetka in konca doživela odziv tudi v osnovnošolskem okolju. V Cerknem so osnovnošolci opravili raziskovalno nalogo in najpomembnejše izsledke objavili $\mathrm{v}$ informatorju občine Cerkno Ukopditi. Članek s fotografijami nekaterih najpomembnejših spomenikov in pokopališč ob soški fronti je po pripovedovanju Janka Razpeta iz Bukovega napisala Petra Klasič.

Grozote frontnega bojevanja in razdejanost pokrajine nazorno predstavlja Marko Štepec v prispevku Bedna kritja pod planoto tik nad Sočo ... (Štepec 2016: 29-38), kjer je danes ohranjenih kar nekaj v našem članku obravnavanih lokacij s spomeniki, znamenji ter vojaškimi bolnišnicami in grobišči.

Grozote vojne, razuzdano življenje, oholost vojaških poveljnikov ter bedno življenje navadnih vojakov med prvo svetovno vojno nam je v obliki dnevniških zapisov ohranil Filip Jankovič. V knjižni obliki z naslovom Pa zbogom, junaki ... Vojni dnevnik Filipa Jankoviča 
je častnikove dnevniške zapise objavila Radiotelevizija Slovenija, Založba kaset in plošč, pod uredništvom Maje Kač (Jankovič - Kač, 2017). Tudi tam je objavljenih več zapisov in slikovnega gradiva, povezanega z v tem članku obravnavano tematiko.

Za pričujočo raziskavo je bil pomemben zlasti Vodnik po arhivskem gradivu 1. svetovne vojne (Volčjak idr. 2017), ki so ga v elektronski obliki objavili večinoma sodelavci slovenskih arhivskih ustanov. Gradivo je predstavilo deset slovenskih arhivskih ustanov, pri njegovem urejanju in komentiranju poglavij pa je sodelovalo petinštirideset uglednih strokovnjakov.

Na spletnih straneh je dosegljiv vsebinsko bogat članek Damirja Globočnika Spomenika padlim v 1. svetovni vojni v Škofji Loki in Stari Loki, v katerem je avtor zbral vrsto podrobnih podatkov o nastajanju dveh spomenikov v Škofji Loki, ki sodita med najvidnejše spomenike padlim in pogrešanim vojakom v prvi svetovni vojni. Že v času njunega odkritja sta vzbudila veliko pozornost, o čemer so poročali takrat vodilni slovenski časniki.

Oktobra 2018 je v Ljubljani potekal dvodnevni simpozijJugoslovanski spomeniki, povezani s 1. svetovno vojno (1918-1941), ${ }^{9}$ na katerem je sodelovalo več strokovnjakov z območja nekdanje skupne države Jugoslavije. Poudarek je bil predvsem na predstavitvi najpomembnejših in likovno najvidnejših spomenikov, ki imajo poleg avtorskih tudi velik prostorski pomen. Morda so nekoliko izostali poudarki o likovno manj atraktivnih znamenjih, ki zgolj dokumentirajo dogodke iz obdobja prve svetovne vojne in let po njej.

$\mathrm{V}$ zvezi s pridobivanjem podatkov o posameznih dogodkih med vojno in postavljanju spomenikov prve svetovne vojne velja izpostaviti vsaj dva prispevka. Prvi govori o postavitvi džamije v Logu pod Mangartom novembra 1916 za potrebe verske oskrbe muslimanskih vojakov v enotah avstro-ogrske vojske, ${ }^{10}$ drugi z naslovom Plečnik in Koroška, ki ga je podpisal Matija Miler, pa med drugim govori o postavitvi Plečnikovih spomenikov žrtvam prve in druge svetovne vojne $\mathrm{v}$ Črni na Koroškem ter spomenika Franju Malgaju v Dobrijah. ${ }^{\mathbf{1 1}}$

Poleg navedenih virov in literature je bila za pričujočo raziskavo pomembna izdaja topografskega pregleda Spomeniki prve svetovne vojne, ki je nastajal kot raziskovalna naloga študentov Oddelka za

9 Spletni vir: http://www.igorzabel.org/30ta-zlozenka-a5_slo-fin.pdf, prevzeto 17. 10. 2018.

10 Log pod Mangartom, džamija. Spletni vir: http://www.logpodmangartom.si/dzamija. pdf, prevzeto 19.9. 2018.

11 Miler, Matija, Plečnik in Koroška. Spletni vir: http://www.matijamiler.net/plecnik. pdf, prevzeto 31.12 .2018$. 
etnologijo in kulturno antropologijo Filozofske fakultete Univerze v Ljubljani pri predmetu Socialni spomin in kulturna dediščina. Za objavo na spletnih straneh je zbrano besedilo uredila Anja Moric (2018).

Poleg omenjenega topografskega delovanja študentov etnologije je bil za zbiranje podatkov o spomenikih prve svetovne vojne uporaben tudi Portal Arzenal s projektnim naslovom Spomeniki 1. svetovne vojne, ki sta ga na spletnih straneh objavila Filozofski inštitut ZRC SAZU in Zgodovinski inštitut Milka Kosa ZRC SAZU (Portal Arzenal, 2018). Gradivo je razvrščeno po abecednem seznamu krajev in večinoma opremljeno $s$ krajšim ali izčrpnejšim ${ }^{\mathbf{1 2}}$ opisom in fotografijami spomenikov.

V pričujoči raziskavi sta bila poleg omenjenih virov uporabljena zlasti zgoraj omenjena topografska pregleda (Moric 2018; Portal Arzenal, 2018) spomenikov in znamenj prve svetovne vojne. Na podlagi teh virov in nato terenskih ogledov posameznih enot je nastajala baza podatkov o vojaških pokopališčih, kapelicah, spomenikih in znamenjih prve svetovne vojne ter o spomenikih znanih osebnosti. Zbranih je bilo tudi več pripovedi informatorjev o nastajanju in vzdrževanju posameznih enot dediščine ter obujanju spominov na prvo svetovno vojno, katerih obseg se je povečal ob stoletnici spominjanja začetka in konca vojne. Nastala je baza podatkov, ki je avtorju omogočala tematsko raznovrstno analizo obravnavane problematike.

Ob navedenih virih in literaturi velja izpostaviti še nekatere vsebinsko, slikovno in oblikovno izstopajoče knjige, s katerimi so izdajatelji želeli nagovoriti kupce. Objavili so nekaj odmevnih knjižnih del, ki so bila večinoma razprodana že pred koncem spominjanja druge obletnice vojne. Med vsestransko zanimivimi in uporabnimi tudi za naše delo velja izpostaviti knjige Bojevnik. Spomini vojnih veteranov prve svetovne vojne (Žebovec 2014), 1. svetovna vojna. Veliki ilustrirani vodnik (Granta 2014), Prestolonaslednikova smrt (Rahten 2014) in Leta strahote. Slovenci in prva svetovna vojna (Svoljšak, Antoličič 2018).

\section{METODOLOGIJA}

V pričujoči raziskavi je bilo obravnavanih skupno 459 enot dediščine, ki so tematsko razporejene $\mathrm{v}$ obravnavane skupine $\mathrm{z}$ namenom izpostaviti njihovo pričevalnost, številčnost ter prostorski, časovni, likovni, 
socialno-etnološki, materialno-tehnični, funkcionalni ter izvedbeni pomen $\mathrm{z}$ vidika avtorstva načrtovanja in izvedbe. Predpostavljam, da $\mathrm{v}$ raziskavi niso bile upoštevane vse obravnavane enote dediščine in da so nekatere ostale spregledane. Med raziskavo je bilo mogoče prepoznati delni izpad določene enote dediščine iz spomina lokalnega prebivalstva, saj so določeno lokacijo presegli poznejši dogodki, ki so v vrednotah lokalne skupnosti postali pomembnejši. Značilen primer je lokacija vojaškega pokopališča iz prve svetovne vojne na zunanji strani pokopališča v Šentvidu nad Ljubljano, ki je v zavesti krajanov postala pomembnejša zaradi dogajanja takoj po drugi svetovni vojni.

Zaradi obsežnosti in pričevalnosti obravnavanih enot dediščine v pričujočem besedilu ni bilo mogoče opisno predstaviti vseh evidentiranih enot, zato so vsebinsko predstavljeni le izbrani primeri, medtem ko je glavnina enot zabeležena le v priloženih seznamih. Dediščina vojaških pokopališč, kapelic, spomenikov in spominskih znamenj prve svetovne vojne na Slovenskem je namreč dokaj obsežna in raznovrstna raziskovalna naloga, ki ji je bilo treba poiskati ustrezno in predvsem pregledno sistemsko obravnavo, temelječo predvsem na časovnem zaporedju in prostorsko-likovnem izrazju teh spomenikov. Vojaškim pokopališčem torej sledijo sakralne enote (kapelice, mošeja idr.), nato pa samostojno stoječi spomeniki in spominska znamenja, večinoma pripojena na vidne sakralne objekte.

Ta dediščina je bila doslej obravnavana predvsem posamično, le redki so pregledi sistematičnega evidentiranja in interpretiranja; takšno je na primer delo Špelce Ćopič (1987), v katerem avtorica z likovnega zornega kota obravnava najpomembnejše spomenike prve svetovne vojne. Topografsko uporaben, vendar metodološko premalo izenačen pregled dediščine prve svetovne vojne so pripravili študentje Oddelka za etnologijo in kulturno antropologijo FF UL (Moric, 2018) ter sodelavci znanstvenoraziskovalnega centra SAZU (Portal Arzenal, 2018), o čemer je že tekla beseda. V našem poskusu smo želeli nadgraditi sistematičen evidenčni model obravnavane dediščine, kar je omogočilo vrsto primerjalnih analiz, ki pa jih v omejenem obsegu tega članka ni bilo mogoče zaobjeti.

Izpostaviti velja še likovni pomen nekaterih upodobljenih oseb. Številčno izstopajo avstro-ogrski vojaki in častniki (Rudolf Maister), sledijo jim figuralne upodobitve svetnikov skupaj s klečečimi ali zamišljenimi vojaki ter reliefne upodobitve ranjenih in umirajočih vojakov, ki jih tolažijo različne svetniške podobe, morda tudi matere. Zelo raznolika je tudi umetniška kakovost upodobljenih likov, saj je bilo mogoče zaobjeti vrhunske likovne upodobitve, pa tudi takšne, ki jih je predvsem v reliefni obliki izvedla manj vešča 
kamnoseška roka. V naši obravnavi so zaobjete vse omenjene likovne razsežnosti, kar je avtorja vodilo še do drugih oblik vrednotenja in razvrščanja obravnavanih enot dediščine predvsem po njihovi časovni in prostorski umeščenosti $\mathrm{v}$ prostor.

Nekatera izstopajoča likovna dela znotraj obravnavanih enot dediščine so že kmalu po nastanku pridobila poseben družbeno prepoznavni značaj, ki ni bil zgolj likovne, temveč nacionalno karakterne narave. Takšen značaj sta namreč pridobila lik avstro-ogrskega vojaka - kranjskega Janeza - pred kostnico na ljubljanskih Žalah in na visok kamnit podstavek nameščen doprsni kip žalujoče Slovenke, odete v gorenjsko narodno nošo, na nekdanjem vojaškem pokopališču v Škofji Loki.

\section{VOJAŠKA POKOPALIŠČA, GROBIŠČA IN GROBNICE}

Prvi veliki spopad narodov in narodnosti v zgodovini se je v spletu več različnih okoliščin (na primer sarajevski atentat 28. junija 1914 na avstro-ogrskega prestolonaslednika Franca Ferdinanda in njegovo ženo Sofio) začel 28. julija 1914 in je trajal do 11 . novembra 1918. V spopade so bile vpletene štiri velike države centralnih sil ${ }^{\mathbf{1 3}}$ in sedemnajst antantnih sil, torej večina evropskih držav. ${ }^{\mathbf{1 4}} \mathrm{V}$ spopadu, ki so mu po izbruhu doslej največje, druge svetovne vojne dodali oznako prva svetovna vojna, je po nekaterih podatkih ${ }^{\mathbf{1 5}}$ na strani centralnih in antantnih sil skupaj umrlo 9.911.000 vojakov, pogrešanih je bilo 7.750.000, ranjenih pa 21.219.500. Zato je dejansko mogoče govoriti o véliki vojni, kakršne do takrat še ni bilo. $\mathrm{V}$ prvi svetovni vojni so bila prizadeta predvsem frontna območja oziroma frontne linije, kjer je bilo mogoče zaradi razmeroma statičnega vojskovanja zgraditi vso potrebno infrastrukturo, oskrbovalna središča in številne poljske bolnišnice, ob katerih so nastajala številna vojaška pokopališča in grobišča.

$\mathrm{Na}$ osnovi terenskih raziskav in zbiranja podatkov iz dosegljive literature in zlasti spletnih virov se je v nekaj mesecih v naši bazi podatkov nabralo 94 enot lokacij, ki jim je mogoče zanesljivo potrditi prvotni namen, torej da so bila (ali so še) na tistih mestih vojaška 
pokopališča in grobišča. Zelo verjetno je bilo takšnih lokacij še več, saj je znano, da so bile vojaške bolnišnice in okrevališča tudi v Kidričevem, Ormožu, Laškem in Rogaški Slatini, kar dokazujejo ohranjene fotografije, vendar se je spomin na kraj pokopov ponekod z leti izgubil. Izpad iz javnega spomina je značilen za Šentvid nad Ljubljano, kjer so imele vojaške oblasti v dokaj novih Škofovih zavodih nameščeno vojaško bolnišnico, pokopališče umrlih vojakov pa je ležalo vzdolž zunanje strani zahodnega pokopališkega zidu ob župnijski cerkvi sv. Vida, kar je domačinom povsem ušlo iz spomina.

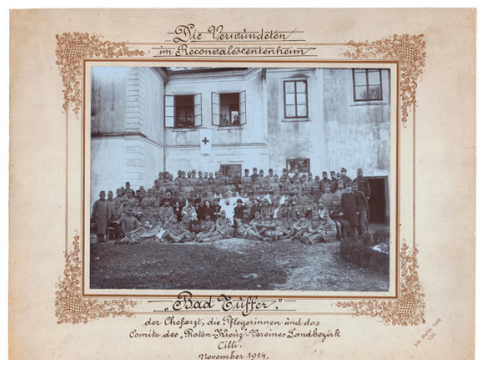

Slika 7: Okrevališče avstro-ogrskih vojakov v zdravilišču Laško (Bad Tüffer) s prvimi ranjenimi vojaki in zdravstvenim osebjem novembra 1914 (foto: Joh. Martin Lanz, Cilli/Celje, vir: Muzej Laško). ${ }^{\mathbf{1 6}}$

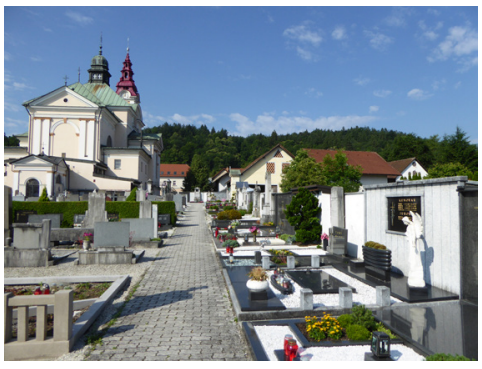

Slika 8: Šentvid nad Ljubljano, pokopališče in župnijska cerkev sv. Vida. Desno za pokopališkim zidom je bilo med prvo svetovno vojno vojaško pokopališče umrlih vojakov, ki so se kot ranjenci zdravili v Zavodu sv. Stanislava (foto: Vito Hazler, 20. 6. 2019).

Prva vojaška pokopališča so na današnjem slovenskem ozemlju nastala z odprtjem soške fronte. Tam so se prvi boji začeli 23. maja 1915, ko so italijanske enote prestopile mejo ter začele napredovati v notranjost takratne Avstro-Ogrske. Zaradi počasnega napredovanja in neodločnosti italijanske vojske je avstro-ogrski vojski še pravočasno uspelo organizirati obrambo ob reki Soči, zaradi česar je italijansko napredovanje zastalo. Tako se frontna linija v korist ene ali druge bojujoče se strani ni bistveno premaknila vse do znamenite 12. soške ofenzive. V bitki, ki je trajala od 24. do 27. oktobra 1917, so nemške in avstro-ogrske sile prodrle do Piave. Do takrat so na obeh straneh preštevali le ogromne izgube med vojaki, častniki, ranjenci ter med bolniškim in drugim osebjem v neposrednem zaledju fronte, pa tudi med civilisti.

Zaradi bolj ali manj nespremenljive frontne linije sta bojujoči se strani utrjevali položaje in $\mathrm{v}$ skale kopali jarke, podzemeljske kaverne in ponekod tudi kapelice (npr. Mrzli vrh v Krnskem pogorju). V bližini 
bojišč so bile namreč tudi bolnišnice in ob njih vojaška pokopališča, saj je bila smrtnost med ranjenci razmeroma visoka. Vojaki so umirali predvsem med velikimi frontnimi spopadi, kar je mogoče razbrati iz napisov na posameznih grobovih, na primer $\mathrm{v}$ Logu pod Mangartom, Soči in drugod, pa tudi tedne ali mesece pozneje, kar lahko razberemo iz pokopališč v zaledju, na primer na vojaškem pokopališču na griču Rebro pri Bohinjski Bistrici. Tam je pokopan vojak Franc Iran, ki je umrl 28. novembra 1916, torej kar 24 dni po koncu 9. soške bitke, ${ }^{17} \mathrm{v}$ kateri je bil (domnevno) težko ranjen in je nato umrl med zdravljenjem v bohinjski vojaški bolnišnici.

Po dostopnih podatkih je vojaških pokopališč, grobišč in grobnic največ v zahodni Sloveniji, torej vzdolž črte soške fronte, postopoma pa se redčijo, ko gremo $\mathrm{v}$ notranjost dežele. $V$ številnih večjih krajih v zaledju so bile vojaške bolnišnice in okrevališča v nekaterih takrat že uveljavljenih termalnih zdraviliščih, na primer v Rogaški Slatini ${ }^{\mathbf{1 8}}$ in Laškem. ${ }^{\mathbf{1 9}}$

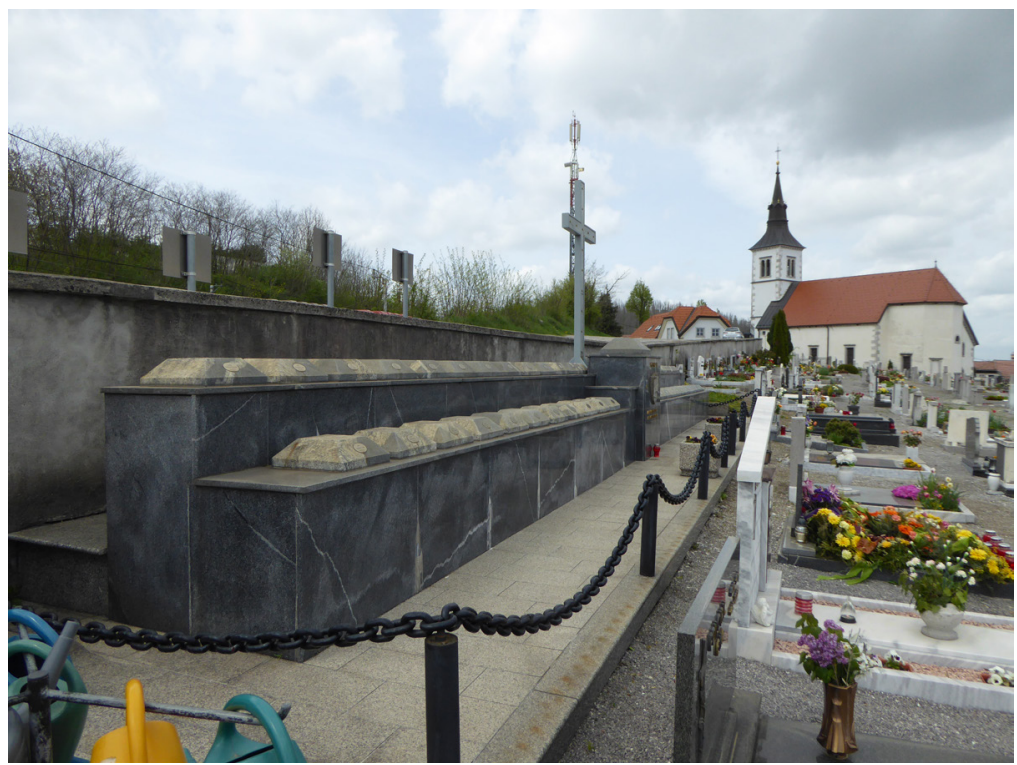

Slika 9: Pivka. Nova grobnica umrlih avstro-ogrskih vojakov na pokopališču jugovzhodno od cerkve sv. Petra (foto: Vito Hazler, 25. 4. 2019).

Po uradnih podatkih je 9. soška bitka trajala od 31. oktobra do 4. novembra 1916. domu. Doslej še niso bila potrjena predvidevanja o morebitnih pokopih umrlih ranjenih vojakov na okoliških pokopališčih. 
Dosegljivi podatki kažejo, da je največ vojaških pokopališč v občinah Nova Gorica in Tolmin, in sicer 17, v občini Komen 9, v občini Renče - Vrtojba 7, v občini Bovec 6, v občini Bohinj 5, po 3 jih imajo občine Ajdovščina, Kanal ob Soči, Kranjska Gora, Ljubljana, Miren - Kostanjevica in Sežana, po 2 jih imajo občine Jesenice, Logatec in Vipava, po eno pa občine Divača, Kamnik, Kidričevo, Kobarid, Kranj, Maribor, Pivka ${ }^{20}$ in Škofja Loka. Domnevno so tudi v Laškem, Ormožu in morda še v drugih krajih.

\section{IZBRANI PRIMERI VOJAŠKIH POKOPALIŠČ}

V tem prispevku ni mogoče predstaviti niti vseh vojaških pokopališč niti njihovih najvidnejših likovnih poudarkov. Zato smo izbrali le nekaj tistih, ki s figuralnimi poudarki vidno dopolnjujejo svojo likovno in prostorsko podobo. Za ponazoritev navajamo le nekatera izmed njih.

\section{$\underline{\text { Log pod Mangartom }}$}

Eno najprepoznavnejših pokopališč, h kateremu spada tudi spomenik, je vojaško pokopališče v Logu pod Mangartom, kjer je v štirih terasah pokopanih več kot 800 vojakov. Iz trakastih palic izdelani železni križi so postavljeni na grobove vojakov katoliške vere, na grobovih vojakov muslimanske vere pa so postavljene široke nagrobne plošče. Na vseh nagrobnikih so pritrjene kovinske ploščice z zaporedno številko, imenom in priimkom vojaka ter datumom smrti. Na čelno stran pokopališča so leta 1917 postavili monumentalen spomenik.

Pisec tega besedila je med služenjem vojaškega roka v Jugoslovanski ljudski armadi leta 1987 v Pivki prosti čas preživljal tudi z obiskovanjem okolice. Vojaki fotoaparatov niso smeli imeti, a v spominu pisca je ostala podoba vojaškega pokopališča desno nad cesto iz Pivke proti vojašnici (s severa proti jugu). Takrat so bili v betonskih koritih s pokrovi še ohranjeni ostanki kosti in lobanj vojakov. Podoba takratnega vojaškega pokopališča je bila povsem drugačna od sedanje podobe grobnice, ki je umeščena na pokopališče jugovzhodno od cerkve sv. Petra. $\mathrm{V}$ tej novi grobnici, izdelani iz pohorskega tonalita, so v 45 žarah hranjeni posmrtni ostanki avstro-ogrskih vojakov različnih narodnosti. Domnevno so umrli v bližnji vojaški bolnišnici, saj so nekateri vojaki umrli šele po končani prvi svetovni vojni (na primer Jocklan Josef, † 18. 10. 1919; Tibiol Herman, † 18. 10. 1919). Na grobnici razen simbolnega napisa, imen in priimkov ter datuma smrti vojakov ni nobenega pojasnjevalnega besedila. 


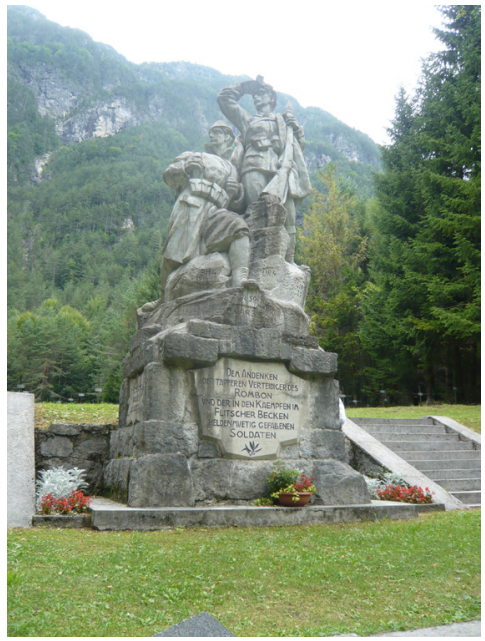

Slika 10: Log pod Mangartom, spomenik, ki ga je leta 1917 na začetku avstro-ogrskega vojaškega pokopališča izdelal češki kipar Ladislav Kofránek. Na spomeniku sta upodobljena bošnjaški vojak $s$ fesom na glavi in vojak katoliške veroizpovedi, kako oprezujeta na bojišču nekje na Rombonu (foto: Vito. Hazler, 25. 7. 2012).

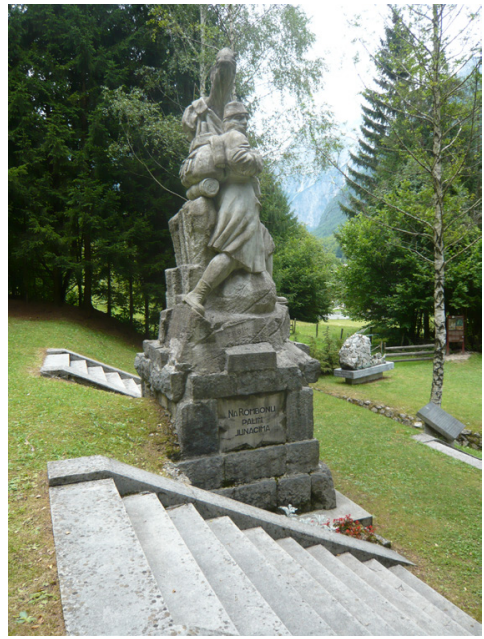

Slika 11: Log pod Mangartom, leva stran spomenika, kjer je upodobljen Bošnjak s fesom v avstro-ogrski uniformi. Pod njim je napis $\gg$ Na Rombonu palim junacima « (foto: Vito Hazler, 25. 7. 2012).

\section{Ljubljana, Žale, italijansko vojaško pokopališče}

Na ljubljanskih Žalah je ohranjeno vojaško pokopališče z geometrično razporejenimi križi okoli osrednjega spomenika. Na tem

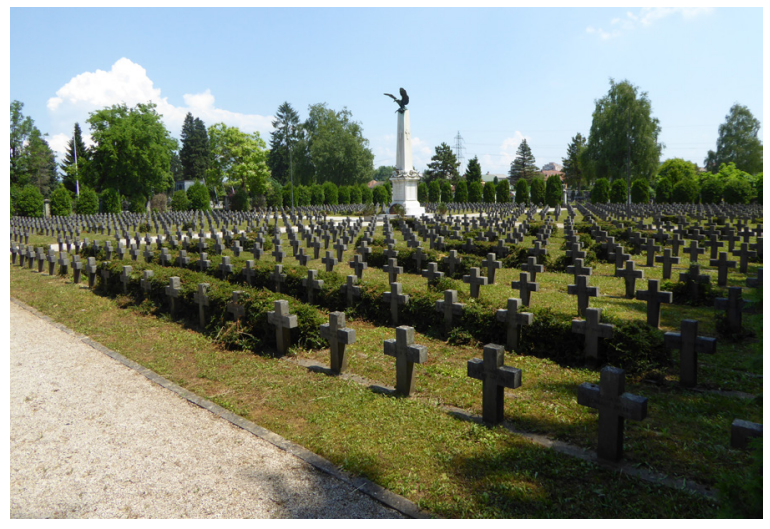

Slika 12: Ljubljana, Žale, italijansko vojaško pokopališče je ohranilo zgolj zunanjo podobo z nagrobniki v obliki križa in osrednjim obeliskom. Leta 1963 so posmrtne ostanke vojakov prepeljali v Italijo (foto: Vito Hazler, 20. 6. 2019). 
pokopališču so bili pokopani italijanski vojni ujetniki z različnih koncev zaledja fronte. Leta 1963 so po predhodni razširitvi pokopališča izvedli popolno ekshumacijo več kot 1000 italijanskih vojakov, katerih posmrtne ostanke so prepeljali v Italijo. Ohranili so se le nagrobniki z imeni in priimki vojakov ter več kot $6 \mathrm{~m}$ visok osrednji spomenik v obliki obeliska, na katerega je postavljen orel z razpetimi krili. Pokopališče s spomenikom je znamenitost Žal ter je redno vzdrževano in pietetno oskrbovano.

\section{Škofja Loka}

Vojaško pokopališče leži vzhodno vzdolž obstoječega mestnega pokopališča v Škofji Loki. Nekateri pisni viri ga označujejo kot vojaško grobišče, informatorji domačini pa ga prepoznavajo kot vojaško pokopališče. Na njem so pokopani avstro-ogrski vojaki, umrli v vojaških bolnišnicah med letoma 1915 in 1918. Danes je na pokopališču $\mathrm{v}$ podobi brezovega gaja ohranjen le en nagrobnik vojaka z napisom: $\gg$ Heinrich Pavlik K. u. K Postamtsdiener geb. 1876 gest. 1916 die Kameraden des 15 . K. K«, na njem pa je tudi osrednji spomenik z doprsnim kipom, znanim pod imenoma žalujoče Slovenke. Spomenik je v obliki herme zasnoval kipar Ivan Jurkovič. Na podstavku so zapisana imena in priimki petih slovenskih častnikov avstro-ogrske vojske in 155 vojakov.

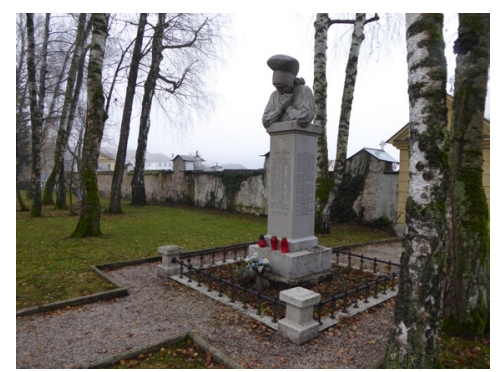

Slika 13: Škofja Loka, vojaško pokopališče s spomenikom slovenske matere kiparja Ivana Jurkoviča iz leta 1928 (foto: Vito Hazler, 10. 12. 2018).

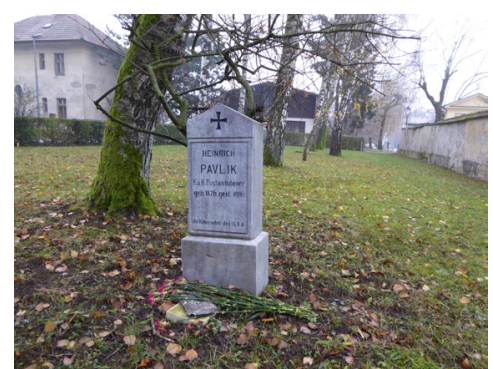

Slika 14: Vojaško pokopališče in edini ohranjeni nagrobnik Heinricha Pavlika (foto: Vito Hazler, 10. 12. 2018). 


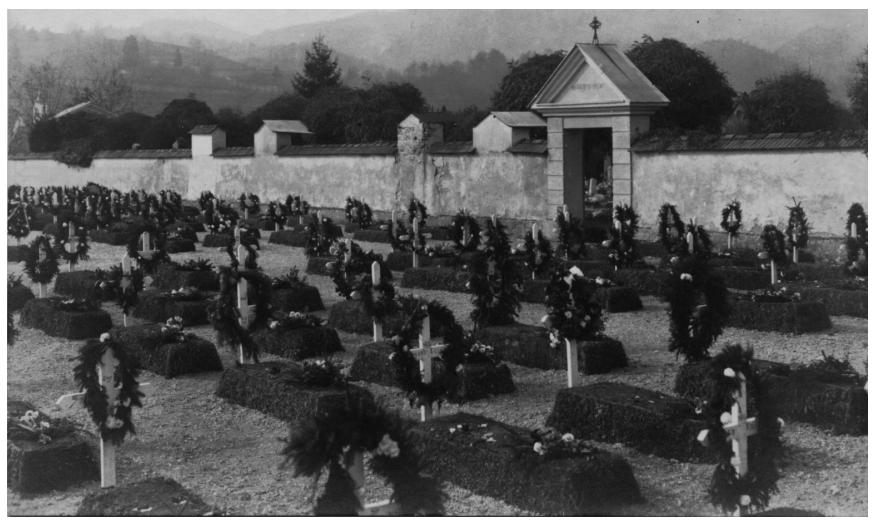

Slika 15: Škofja Loka, urejeni grobovi vojakov. Zbirka Dominika Podnarja.

\section{ARHITEKTURNI POUDARKI VOJAŠKIH POKOPALIŠČ}

Nekatera vojaška pokopališča na Slovenskem imajo v svojem sestavu monumentalne objekte, ki jih je mogoče prepoznati kot pokopališki mavzolej ter so med vsemi pokopališkimi sestavinami prostorsko in likovno najbolj dominantni. Takšen pokopališki mavzolej imata vojaški pokopališči v Gorjanskem in Štanjelu na Krasu.

V Gorjanskem je pokopališki mavzolej postavljen na najvišji robni del pokopališča, od koder so po več pokopnih poljih razporejeni grobovi z nagrobniki padlih vojakov. Osrednji mavzolej so začeli graditi že med vojno, julija 1916, in ga v celoti s kraškim kamnom dokončali v obliki osrednjega, s kupolo poudarjenega objekta, ki je s čelne strani odprt, levo in desno pa se ga skorajda dotikata arkadi s po štirimi loki. Mavzolej je zgrajen iz geometrijsko obdelanih blokov in bokov z rustiko. Pod to osrednjo pokopališko stavbo so v več pravilnih geometrijskih poljih razporejeni grobovi vojakov in častnikov. Morda gre za največje vojaško pokopališče na območju soške fronte. Po nekaterih navedbah naj bi bilo tam pokopanih 10.000 avstro-ogrskih vojakov, ${ }^{\mathbf{2 1}}$ po drugih $6015^{22}$ in po tretjih $14.000 .^{23}$ slovenija/vojasko_pokopalisce_gorjansko/slo, prevzeto 19.10.2018. Spletni vir: Gorjansko, vojaško pokopališče iz prve svetovne vojne, http://www. potmiru.si/slo/gorjansko, prevzeto 21. 10. 2018.

23

Spletni vir: Seznam dediščine prve svetovne vojne, vključene v register nepremične kulturne dediščine, http://www.potmiru.si/unesco/Seznam_vojaskih_pokopalisc_in_ kostnic_2017.pdf, prevzeto 4. 12. 2018. 


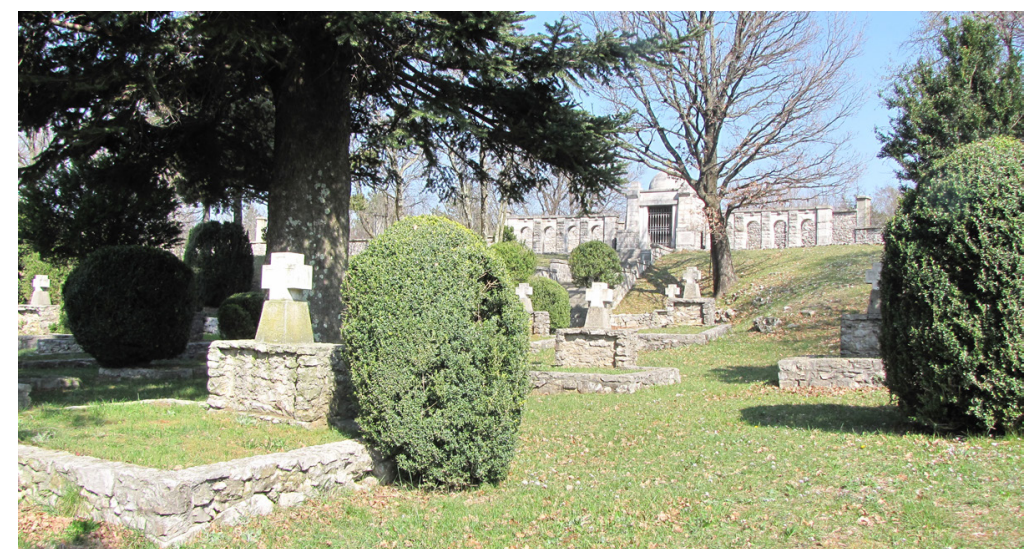

Slika 16: Gorjansko, avstro-ogrsko vojaško pokopališče (foto: Vito Hazler, 14. 3. 2014).

Značilno osrednjo in dominantno stavbo na zgornji robni strani ima tudi avstro-ogrsko vojaško pokopališče v Štanjelu. Pokopališče ima značilno geometrijsko razporeditev grobnih polj in dominantni položaj osrednje pokopališke stavbe, ki je v nekem spletnem viru označena kot »večji skupni spomenik oz. dorski tempelj s secesijskimi elementi ${ }^{\mathbf{2 4}}$

\section{KOSTNICE}

Med vidne sestavine dediščine prve svetovne vojne sodijo tudi kostnice, grobnice in skupna grobišča, kjer so praviloma pokopani pripadniki le ene vojskujoče se skupine. Zlasti kostnice in grobnice pri obiskovalcih vzbujajo še posebno pozornost in spoštljiv odnos, saj so tam na nekoliko drugačen, po nekaterih ocenah bolj svečan način zadnje počivališče dobili vojaki, ki so padli v bojih ali umrli v bolnišnicah. Takšnih objektov je v Sloveniji pet; so različnih oblik in velikosti ter likovno izvirno oblikovani, zato so pomemben del svojega kulturnega okolja.

\section{$\underline{\text { Komna, planina Na Kraju }}$}

Vzhodno od soške fronte je na Komni na planini Na Kraju ohranjena kostnica padlih avstro-ogrskih vojakov v prvi svetovni vojni.

24 Spletni vir: Štanjel, avstro-ogrsko vojaško pokopališče iz prve svetovne vojne, https://www.visitkras.info/kras_in_brkini/kulturna_dediscina/1_in_2_svetovna_ vojna/2014021016103341/, prevzeto 19. 10. 2018. 
Zasnovana je kot kamnita piramida z vzidano marmornato ploščo. Število pokopanih ni znano. Postavljena je bila v drugem desetletju 20. stoletja. Spomeniškovarstvena služba jo ima evidentirano pod oznako EŠD 16925.

\section{Jesenice, Spominski park na Plavžu}

V spominskem parku na Plavžu je ohranjena kapela s kostnico padlih vojakov v prvi svetovni vojni 1914-1918. Kapelo so zgradili v letih 1927-1929 po načrtih Gerharta Luckmanna in leta 1931 so v kostnico prenesli posmrtne ostanke 28 vojakov domačinov z jeseniškega pokopališča, leta 1937 pa še posmrtne ostanke 50 vojakov z vojaškega pokopališča v Kranjski Gori in posmrtne ostanke devetih ruskih vojakov z vojaškega pokopališča na Hrušici. ${ }^{25}$ Kapela je pravokotniškega tlorisa s štirikapno streho in stolpičem $s$ križem na slemenu. Pred vhodom ima odprto lopo z ravno streho, na katero je postavljen kip krilatega angela. V notranjosti kapelice stojijo veliko razpelo, lesena oltarna miza z napisom Marija, ambon in nekaj klopi. Na prekladi nad vhodom sta letnici $1914-1919 .^{26}$

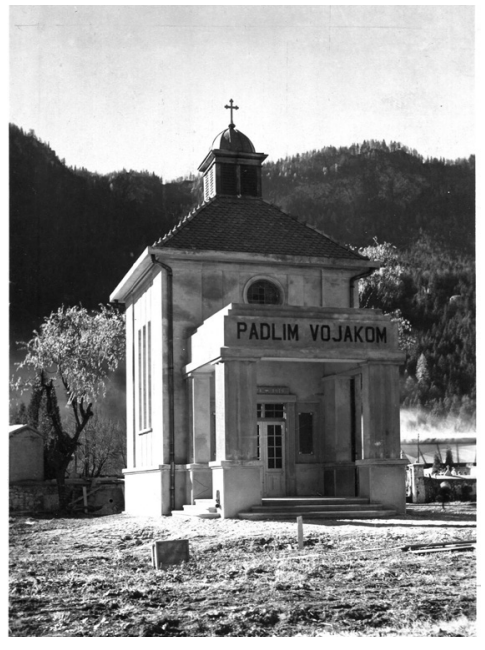

Slika 17: Jesenice, Luckmannova kostnica iz leta 1929 (foto: Vilman, 1929, fotografijo posredoval Janez Bogataj).

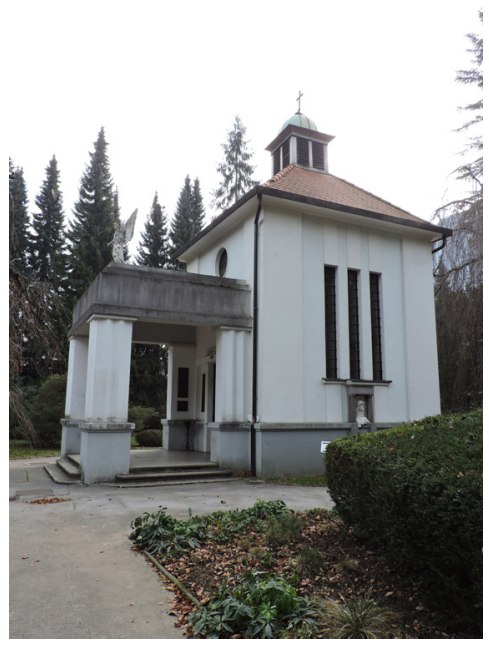

Slika 18: Jesenice, Spominski park na Plavžu, današnja podoba Luckmannove kostnice iz leta 1929 s posmrtnimi ostanki v prvi svetovni vojni padlih vojakov (foto: Mojca Bele, 1. 12. 2018). 
$\mathrm{Na}$ Gradiču nad Kobaridom so takratne italijanske oblasti v letih 1935-1938 ob cerkvi sv. Antona (1669) zgradile največjo kostnico na današnjem slovenskem ozemlju. Vanjo so bili preneseni posmrtni ostanki okrog 7760 padlih vojakov ${ }^{27} \mathrm{v}$ prvi svetovni vojni, ki so jih tja prenesli z vojaških pokopališč v okolici Kobarida, Bovca, Tolmina in Rambona. Kostnico sta oblikovala kipar Giannino Castiglioni in arhitekt Giovanni Greppi. Viri navajajo, da je bil na slovesnosti ob njenem odprtju prisoten Benito Mussolini. ${ }^{28}$

\section{Ljubljana, pokopališče Žale, kostnica}

Ljubljana je bila med prvo svetovno vojno, zlasti pa v letih 1915-1917, glavno logistično središče soške fronte, kar je močno zaznamovalo življenje meščanov. Na pokopališču pri Sv. Križu so pokopavali vojake in že med vojno se je porodila zamisel o postavitvi ustreznega spominskega znamenja. Delo za postavitev vidnega spomenika, ki se ga je pozneje prijelo ime spomenik kranjskega Janeza, so zaupali kiparju Svitoslavu Peruzziju, ki je z delom začel leta 1916, kip pa je leta 1917 dokončal kipar Lojze Dolinar. Leta 1923 so ga postavili na grob judenburških žrtev na ljubljanskih Žalah. Kasneje je bil prestavljen pred kostnico žrtev prve svetovne vojne, ki so jo v letih 1938-1939 zgradili po načrtih arhitekta Edvarda Ravnikarja. Pozneje se je kostnice prijelo ime kostnica kranjskih Janezov.

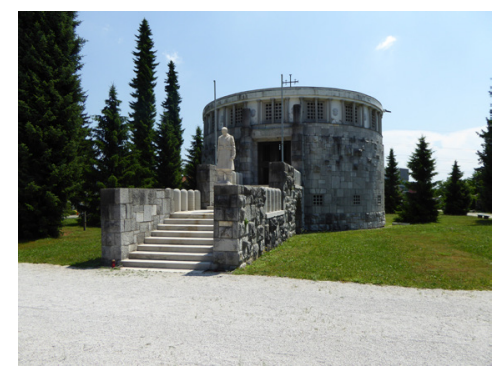

Slika 19: Ljubljana, pokopališče Žale. Kip kranjskega Janeza iz leta 1917 na ploščadi kostnice s posmrtnimi ostanki v prvi svetovni vojni padlih avstro-ogrskih vojakov (foto: spletni vir, prevzeto 29.12.2018).

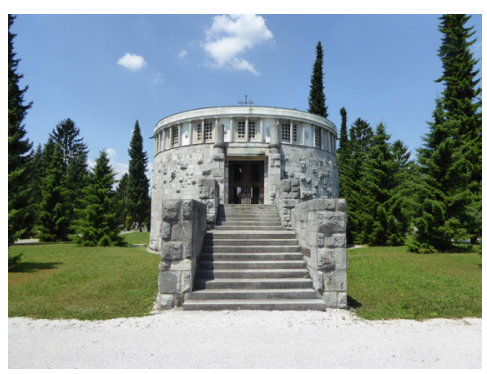

Slika 20: Ljubljana, pokopališče Žale. Kostnica iz leta 1939 (foto: spletni vir, prevzeto 29. 12.2018). 
V Mariboru so v začetku prve svetovne vojne preminule vojake sprva pokopavali na mestnem, nato pa na pobreškem pokopališču, ki je bilo leta 1914 blagoslovljeno in je postalo osrednje pokopališče mesta. ${ }^{29}$ Tam so pokopavali vojake iz različnih vojaških bolnišnic in vojne ujetnike. $\mathrm{Na}$ pokopališču je bilo pokopanih okoli tisoč padlih vojakov, Slovencev, Avstrijcev in Nemcev ter ruskih in italijanskih vojnih ujetnikov. Leta 1932 so za vse padle in umrle vojake uredili skupno kostnico, ${ }^{\mathbf{3 0}}$ kamor so prenesli ostanke 954 vojakov, ki so jih med vojno pokopavali na različnih koncih pokopališča in na mestnem pokopališču. Leta 1933 so izkopali ostanke 119 padlih vojakov in jih prepeljali v Italijo.

\section{$\underline{\text { Tolmin, nemška kostnica }}$}

Nemška kostnica pri Tolminu je povezana z dogodki odločilne 12. soške bitke, znane pod imenom prodor pri Kobaridu (tudi čudež pri Kobaridu), ki je potekala od 24. do 28. oktobra 1917. V spopadu so sodelovale 1. in 2. soška armada ter dodatnih dvanajst divizij 14. skupne nemško-avstrijske armade. Na kraju, kjer je bilo prvotno vojaško pokopališče z 931 grobovi, je v letih 1936-1938 nemška država zgradila kostnico po načrtih nemškega arhitekta Roberta Tischlerja, ki jo je zasnoval kot utrdbo.

\section{KOSTNICE NA ITALIJANSKI STRANI SOŠKE FRONTE}

Med najbolj znanimi in tudi po številu posmrtnih ostankov najštevilčnejšimi sta kostnici v Oslavju in Sredipolju v bližini slovensko-italijanske meje. Poleg večinoma italijanskih so tam pokopani tudi avstro-ogrski vojaki, med njimi tudi več Slovencev.

\section{Oslavje v Goriški pokrajini, Italija}

V Oslavju v bližini Gorice so leta 1938 vrh griča postavili veliko kostnico padlih italijanskih vojakov v prvi svetovni vojni. Kostnica je 215-18).

30 Nekateri viri jo označujejo kot »grobnico padlih vojakov« (spletni vir: Muzej novejše zgodovine, http://www.muzej-nz.si/sl/pages.php?id_meni=69\&id=18, prevzeto 28. 1 . 2019). 
delo rimskega arhitekta Ghina Venturija. V njej je pokopanih 57.200 italijanskih vojakov 2. armade ter 539 avstro-ogrskih vojakov, katerih posmrtne ostanke so prenesli v kostnico z italijanskih pokopališč med Banjško planoto, reko Vipavo in Gorico. ${ }^{31}$

\section{Sredipolje, Redipuglia, Italija}

Kostnica v Sredipolju (Sacrario di Redipuglia) je največji in najveličastnejši spomenik padlim v prvi svetovni vojni v Italiji. Zgradili so jo po načrtih arhitekta Giovannija Greppija in kiparja Giannina Castiglionija (tudi avtorja kostnice v Kobaridu) ter jo svečano odkrili 18. septembra 1938. Hrani posmrtne ostanke kar 100.187 vojakov, ki so padli na tem območju soške fronte.

\section{KAPELICE IN DRUGI MONUMENTALNI SPOMENIKI, POVE- ZANI Z VERSKO OSKRBO V PRVI SVETOVNI VOJNI}

Na ozemlju današnje Slovenije je bilo po dosegljivih virih mogoče evidentirati 56 kapelic in verskih znamenj, ki so neposredno povezane z verskim življenjem pripadnikov večinoma katoliške ter $s$ po enim primerom tudi pripadnikov pravoslavne in islamske verske skupnosti. Kapele in znamenja so večinoma zgradili vojaki na soški fronti ob soglasju in podpori vodstva obeh vojskujočih se strani, postavljali pa so jih tudi slovenski vojaki in njihovi svojci ob srečni vrnitvi domov. Kapele in znamenja so imela obenem tudi velik moralni in etnični naboj, saj so z ideologijo istega ali sorodnega boga sporočale nesmiselnost vojaškega reševanja družbenih težav.

Med obravnavanimi kulturnimi spomeniki je bilo mogoče prepoznati določene razlike predvsem $\mathrm{v}$ ikonografskem in oblikovalskem izražanju, kar je mogoče prepoznati med italijanskimi na eni in avstro-ogrskimi graditelji na drugi strani, še posebej pa pri graditeljih pravoslavne in islamske veroizpovedi, saj sta se edini zgrajeni pravoslavna ruska kapelica pod Vršičem in mošeja v Logu pod Mangartom arhitekturno in ikonografsko bistveno razlikovali od katoliških kapel in drugih verskih znamenj.

Različni so bili tudi razlogi za postavitev obravnavanih verskih objektov, in sicer: 
za potrebe verske oskrbe med vojno (na primer Ladra pri Kobaridu) - 9 enot,

- $\quad$ kot del vojaškega pokopališča (na primer kapelica na vojaškem pokopališču v Ukancu) - 8 enot,

- $\quad$ kot hramba posmrtnih ostankov (na primer kapelica v Spominskem parku Plavž na Jesenicah) - 1 enota,

- $\quad$ kot spomin na srečno vrnitev iz vojne (na primer Mahorjeva kapela v Zaklu iz leta 1926) - 25 enot,

- $\quad$ kot spomin na padle rojake in na prvo svetovno vojno (na primer Logatec, kapelica iz leta 1922) - 12 enot,

- $\quad$ kot opomin na nesmiselnost vojskovanja (na primer pomnik miru in razgledni stolp Cerje $)^{32}-1$ enota.

Poleg izvorne funkcionalne raznolikosti je mogoče prepoznati tudi likovno-oblikovalske posebnosti obravnavanih objektov. Že osnovna primerjalna analiza potrdi domnevo, da je vsaka izmed obravnavanih enot dediščine izvorno zasnovana, čeprav je pri nekaterih mogoče prepoznati tipološke značilnosti okolja, v katero so bile postavljene. Za ponazoritev njihove podobe predstavljamo nekatere izmed njih.

Med likovno in prostorsko najbolj izstopajoče sakralne stavbe iz obdobja prve svetovne vojne sodi kapelica (imenovana tudi kapela, cerkev) sv. Duha v Javorci nad Zatolminom, zgrajena med marcem in novembrom 1916. Zgrajena je bila kot spomin na padle avstro-ogrske vojake na soški fronti, postavil pa jo je dunajski arhitekt, slikar in scenograf Remigius Geyling, ki je takrat kot nadporočnik služil domovini. Vodja del je bil Madžar Geza Jablonsky, zgradili pa so jo vojaki, sicer mojstri različnih gradbeniških obrti. Kapela je zgrajena pretežno iz lesa. V notranjščini prevladujejo modre in bele barve ter secesijske likovne prvine. Posebno vrednost imajo velike lesene plošče z vrezanimi priimki in imeni padlih vojakov in častnikov. Kapela je od leta 2018 uvrščena na seznam evropske kulturne dediščine. ${ }^{\mathbf{3 3}}$

Blizu vasi Ladra pri Kobaridu je ohranjena in pred leti načrtno obnovljena kapela, ki jo je v letih 1916-1917 za lastne verske potrebe zgradila italijanska vojska. Zgrajena je iz kamna in lesa, in sicer po načrtih italijanskega arhitekta Giovannija Micheluccija. Posvetili so jo 30. maja 1917. Novogoriški zavod za varstvo kulturne dediščine je v $S$ tem smo se izognili njihovemu razvrščanju po pripadnosti vojskujočih se strani in verski pripadnosti. So pa pri vseh obravnavanih enotah omenjene tudi te značilnosti. Spletni vir: Cerkev sv. Duha, Zatolmin, https://sl.wikipedia.org/wiki/Cerkev_sv._ Duha,_Zatolmin, prevzeto 10.12. 2018. 


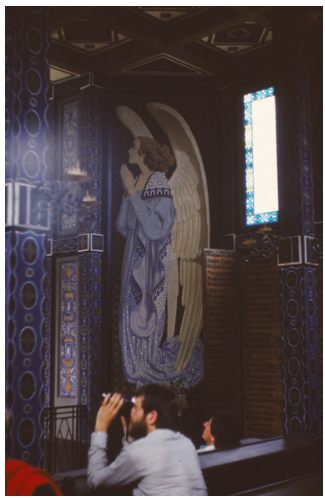

Slika 21: Javorca, kapelica sv. Duha, secesijska poslikava notranjščine (foto: Vito Hazler, maj 1983).

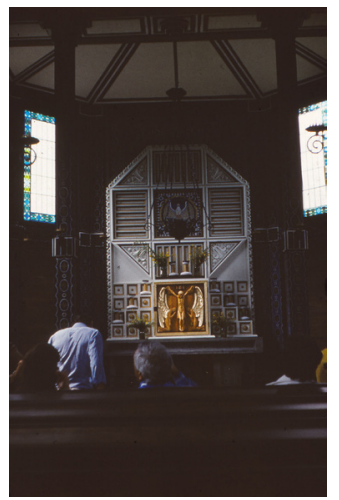

Slika 22: Javorca, kapelica sv. Duha, osrednji oltar (foto: Vito Hazler, maj 1983).

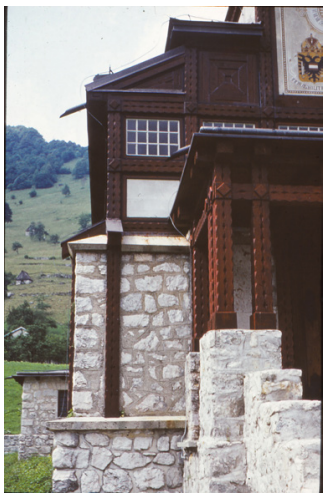

Slika 23: Javorca, kapelica sv. Duha, del zunanjščine po obsežni restavratorski obnovi (foto: Vito Hazler, maj 1983).

letih 1993-2005 vodil temeljito obnovo tega pomembnega in oblikovno izvirnega sakralnega kulturnega spomenika.

Log pod Mangartom je med prvo svetovno vojno sodil v bližnje zaledje soške fronte. Tam so bili nastanjeni vojaki, tam so pokopavali umrle tovariše in tam od leta 1755 stoji katoliška cerkev sv. Štefana. Tam so po nekaterih virih novembra 1916 (po drugih v začetku leta 1917) postavili mošejo za versko oskrbo muslimanskih vojakov, zlasti Bošnjakov, ki so sloveli kot izjemno pogumni in vztrajni borci. Morda so tudi zaradi teh lastnosti dobili priložnost za postavitev svojega svetišča, mošeje, ki so jo zasnovali kot pritlično stavbo kvadratastega tlorisa s pločevinasto kupolo in odprto lopo pred vhodom vanjo ter $s$ štiristranim minaretom $\mathrm{z}$ vitko stožčasto strešico.

Vse kaže, da so za gradnjo mošeje uporabili okoliški apnenec, za prekritje kupole in stožčaste strehe na minaretu pa odsluženo vojaško pločevino. ${ }^{34}$ Očitno so bili tudi med temi avstro-ogrskimi vojaki, Bošnjaki, izvrstni zidarski in drugi mojstri, ki so si na tak način zgradili svetišče. Mošeja je domnevno propadla kmalu po končani vojni, saj zanjo ni nihče več skrbel, domačinom povratnikom pa je bila popolna novost in tujek v prostoru (Avsenak 2006). Od leta 2005 Islamska skupnost v Sloveniji organizira vsakoletna 
srečanja pred spomenikom in pokopališčem v Logu pod Mangartom. Sodeč po razpoložljivem slikovnem gradivu obišče tudi lokacijo nekdanje mošeje.

$\mathrm{Na}$ Planici, na planini Kuhinja, je na nadmorski višini $1220 \mathrm{~m}$ ohranjena italijanska vojaška kapela iz prve svetovne vojne. Stoji nad manjšo pečino med Planino in Plečami, od koder se odpira lep razgled tudi proti dolini reke Soče. Kapela se imenuje po italijanskem stotniku Celestinu Besu, poveljniku istoimenskega posebnega planinskega bataljona, ki se je izkazal v bojih na Rombonu. Stotnik Bes naj bi dal kapelo zgraditi prav v spomin na svoje padle vojake. ${ }^{35}$ Kapela, ki so jo domnevno zgradili okrog leta 1916, je pravokotniškega tlorisa z apsidalno zaključenim zadnjim oltarnim delom. Banjasta streha se $s$ plitkim strešnim zidcem povezuje z ostenjem fasade, ki ima na obeh stranskih fasadah po tri šilaste line. Osrednji poudarek kapele je dimenzijsko izstopajoča bogato členjena čelna fasada, okrašena s prekrižanimi puškami in s po eno kamnito granato na vsaki strani. Na vrh srednjega šilastega loka je pritrjen kip orla z razpetimi krili, povsem na vrhu pa je latinski križ. V dokaj svetli in barvno bogati notranjščini je na oltarni mizi kip pieta. Kapelo je med letoma 1993 in 1996 obnovil Kobariški muzej.

Med najbolj znanimi sakralnimi spomeniki iz obdobja prve svetovne vojne je lesena ruska kapelica nad cesto proti gorskemu prelazu Vršič $(1611 \mathrm{~m})$. Leta 1916 so jo zgradili ruski vojni ujetniki v spomin na tragično preminule rojake, ko se je 12. marca 1916 s strmin Mojstrane utrgal snežni plaz in pod seboj pokopal od 170 do 300 ruskih ter od 10 do 80 avstrijskih vojakov. Ruski vojni ujetniki so gradili cesto čez Vršič, ki naj bi pomembno prispevala k izboljšanju oskrbovanja avstro-ogrskih vojaških enot na soški fronti. Kapelica je zasnovana v slogu ruskih pravoslavnih cerkva. V celoti je zgrajena iz lesa, saj ima leseno osnovno konstrukcijo in zunanjščino ter streho, prekrito $z$ deščicami. Ob strani kapele sta grob z betonskim križem in v obliki piramide zasnovana kamnita grobnica. Na grobnici je napis »Synam Rossii « (Sinovom Rusije). Leta 1985 so kapelico razglasili za kulturni spomenik. Temeljito so jo obnovili leta 2005 pod vodstvom konservatorke Renate Pamić z Zavoda za varstvo kulturne dediščine Republike Slovenije - Območna enota Kranj. Takrat je izšla tudi obsežna monografija o njej (Škodič 2016). 


\section{SPOMENIKI IN SPOMINSKA ZNAMENJA PRVE SVETOVNE VOJNE}

Spomenike in spominska znamenja prve svetovne vojne so po Evropi postavljali na ozemljih tako nekdanjih centralnih kot antantnih sil. Razvila se je raznovrstna kompozicijska in ikonografska podoba spomenikov in najrazličnejših znamenj, pa tudi mesta postavitev so bila zelo različna. Samostojno stoječe spomenike so postavljali ob cestnih križǐ̌čih, $\mathrm{v}$ parkih, $\mathrm{v}$ bližini pokopališč, na pokopališčih ter ob cerkvah in drugih stavbah, znamenja v obliki spominskih plošč pa so vgrajevali na pročelja cerkva in različnih stavb. Vzorec postavljanja je bil soroden našemu, zato velikih odstopanj in posebnosti na našem ozemlju ni mogoče zaznati. $\mathrm{Za}$ ponazoritev navajamo primere iz Madžarske, Avstrije in Nemčije.

Podobno razporeditev poznajo tudi drugod po Evropi, kot na primer v Sloveniji bližnjem Monoštru v Porabju na Madžarskem, kjer imajo samostojen spomenik padlim vojakom $\mathrm{v}$ prvi svetovni vojni. Sorodno umeščen je spomenik v trgu Straden v jugovzhodnem delu avstrijske Štajerske, kjer stoji samostojno pred cerkvijo Matere Božje ter je posvečen padlim v prvi in drugi svetovni vojni. Spomenik ima zanimiv relief $\mathrm{z}$ ikonografskim motivom ležečega ranjenega avstro-ogrskega vojaka in Marije Tolažnice žalostnih z razširjenimi rokami. Ta motiv se nekajkrat pojavi tudi pri spomenikih na slovenskem ozemlju.

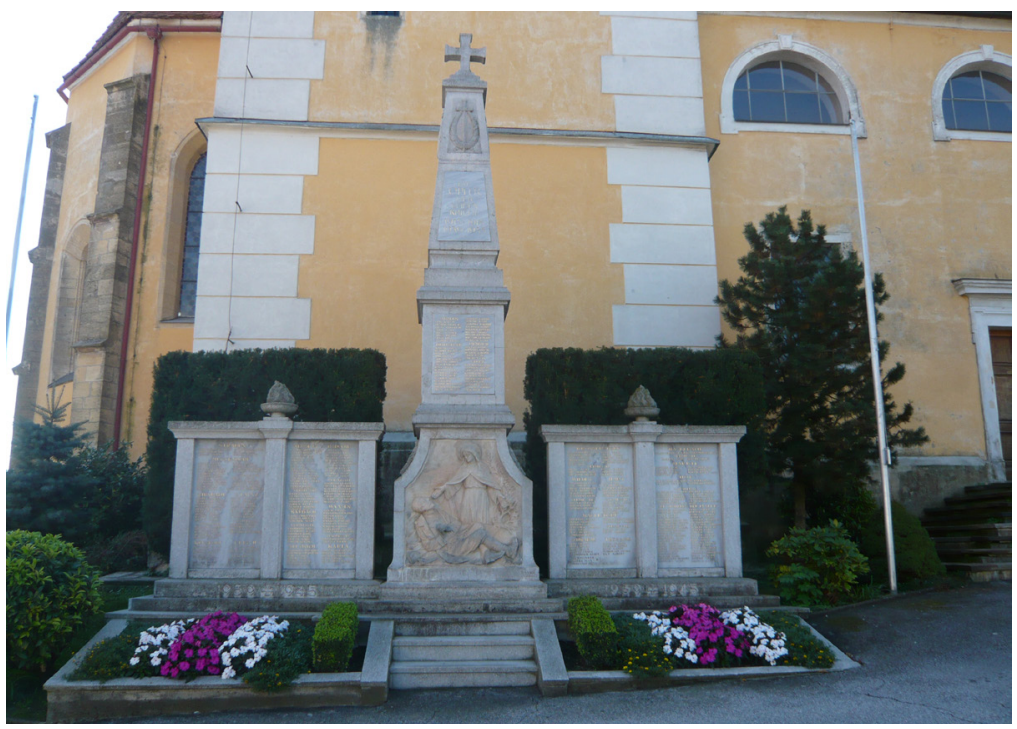

Slika 24: Straden, trg vrh hriba v jugovzhodnem delu avstrijske Štajerske. Pred samostansko cerkvijo Matere Božje stoji spomenik padlim v prvi in drugi svetovni vojni. Na podstavku spomenika je globok relief ležečega ranjenega avstro-ogrskega vojaka in Marije Tolažnice žalostnih z razširjenimi rokami (foto: Vito Hazler, 18. 3. 2010). 
$\mathrm{Na}$ Slovenskem je po nam dostopnih podatkih postavljenih in vgrajenih 276 spomenikov in znamenj, ki so odziv javnosti v smeri krepitve spomina na padle vojake in trpljenje ljudi v času vojne in po njej. Največ zaslug za postavitev večine spomenikov in znamenj ima Zveza bojevnikov $s$ kuratom Francem Bonačem na čelu. Iz nekaterih njenih poročil je mogoče razbrati, da je sodelovala vsaj pri 150 postavitvah (Božidar Jezernik, v tej knjigi).

Spomenike in znamenja so postavljali že v letih takoj po vojni, najbolj pa je postavljanje zaživelo v 1920-ih in 1930-ih letih, le nekaj so jih postavili v letih po drugi svetovni vojni in več ob stoletnicah spominjanja začetka in konca prve svetovne vojne.

Tudi za spomenike in znamenja je značilna avtorska izvirnost, saj so se tako kot arhitekti in kiparji tudi kamnoseški mojstri trudili, da bi za vsakega naročnika izdelali izvirni načrt in končni izdelek. ${ }^{36}$ Tudi zaradi izvirne ustvarjalnosti izvajalcev del je dediščina spomenikov in znamenj prve svetovne vojne zanimivo raziskovalno področje, ki še zdaleč ni osvetljeno z vseh zornih kotov.

O spomenikih prve svetovne vojne je bilo objavljenih več člankov $\mathrm{v}$ tiskani obliki in na spletnih straneh. Med prispevki, ki izstopajo po raziskovalni izvirnosti, velja omeniti zlasti članek Špelce Čopič Slovenski spomeniki padlim v prvi svetovni vojni (Čopič, 1987), monografijo Božidarja Jezernika Mesto brez spomina (2014), zapise Damirja Globočnika na spletnih straneh (2018) in njegov prispevek v tedniku NeDelo (Maselj 2019: 28-9).

Pregled 276 spomenikov in znamenj je omogočil nekatere oblike njihovega razporejanja po osnovnih prepoznavnostih oziroma tipoloških značilnostih. Razporejanje je že v osnovi nehvaležno delo, saj je izrazito avtorsko. Tako ustreznih objektivnih analiz v tem primeru ni bilo mogoče izvesti, saj so obstajale možnosti drobljenja podatkov in s tem kopičenja raznovrstnih skupin. Za najprimernejšo se je izkazala razporeditev po mestu postavitve oziroma vgraditve. Tako so se izoblikovale tri temeljne skupine, ki po našem mnenju dovolj učinkovito ponazarjajo namene in cilje postavljavcev ter sporočilnost spomenikov in znamenj. Prepoznane spomenike je bilo mogoče razdeliti v tri skupine:

1. samostojno stoječe spomenike in znamenja v bližini pokopaličč, v njihovem sestavu ali ločeno samostojno v parku (141 enot), 
2. $\mathrm{v}$ neposredni bližini cerkva in župnišč postavljene ali vgrajene spomenike in znamenja, ki stojijo v neposredni bližini praviloma cerkva in župnišč ter so nanje lahko tudi prislonjeni ali celo vanje vgrajeni ( 25 enot),

3. vgrajene spominske plošče na pročeljih ali v notranjosti cerkva ter na že prej obstoječih kapelah (110 enot).

Zaradi velike količine obravnavanih enot sta iz vsake skupine informativno in ilustrativno predstavljeni le po dve enoti. ${ }^{37}$ Nekatere najpomembnejše so po omenjenih skupinah razporejene po času nastanka, in sicer:

Samostojno stoječi spomeniki in znamenja: v Bohinjski Beli, Vurnikov spomenik pred cerkvijo sv. Marjete; Trbovlje, spomenik padlim v prvi svetovni vojni iz leta 1922; Zgornje Gorje, spomenik ob cestnem križišču iz leta 1924; Grajska vas v Spodnji Savinjski dolini, spomenik ob p. c. sv. Krištofa iz leta 1924; Dovje pri Mojstrani, spomenik ob ž. c. sv. Martina iz leta 1925; Borovnica, spomenik iz leta 1926 ob ž. c. in pokopališču; Preska pri Medvodah, spomenik iz leta 1926 na vaškem pokopališču pod župnijsko cerkvijo; Lukovica pri Domžalah, spomenik sredi trga iz leta 1926; Polzela, spomenik iz leta 1927 ob cerkvi sv. Marjete; Srednja vas v Bohinju, spomenik Ivana Vurnika iz leta 1927; Mengeš, spomenik padlim vojakom iz leta 1927; Črnuče pri Ljubljani, spomenik padlim vojakom v prvi svetovni vojni pred cerkvijo sv. Simona in Juda Tadeja okrog leta 1927; Vodice na Kranjskem polju, spomenik padlim vojakom v prvi svetovni vojni iz leta 1927; Ljubljana, Hrvaški trg s spomenikom padlih vojakov v prvi svetovni vojni iz leta 1927; Šmartno ob Paki, spomenik padlim vojakom v prvi svetovni vojni iz leta 1927 med cerkvijo sv. Martina in pokopališčem; Dob pri Domžalah, spomenik padlim vojakom, delo Toneta Kralja iz leta 1928; Stražišče pri Kranju, spomenik padlim vojakom v prvi svetovni vojni iz leta 1928 na dvorišču pred cerkvijo sv. Martina; Zagorje ob Savi, spomenik padlim vojakom iz leta 1928, zgrajen po načrtih arhitekta Mirka Razingerja; Zasavska Sveta gora, spomenik padlim vojakom iz leta 1929; Videm - Dobrepolje, spomenik prve svetovne vojne iz leta 1930; Črenšovci v Prekmurju, spomenik iz leta 1930 v parku pred ž. c. sv. Križa; Brezovica pri Žirovnici, spomenik padlim v prvi svetovni vojni iz leta 1931; Zavodnje nad Šoštanjem, spomenik padlim iz leta 1931 (obnova 2003); Komenda pri Kamniku, spomenik po načrtih arhitekta Jožeta Plečnika iz leta 1935; Kamnik, pokopališče Žale, zamisel spomenika je razvil slikar in grafik 
Stane Cuderman ob sodelovanju kiparja Borisa Kalina; Kranj, mestno pokopališče na Planini, spomenik prve svetovne vojne iz leta 1939; Črna na Koroškem, spomenik padlim v prvi in drugi svetovni vojni iz leta 1952; Brezovica pri Ljubljani, spomenik prve svetovne vojne iz leta 1919 na pokopališču južno pod župnijsko cerkvijo sv. Antona Padovanskega; Ljubljana, Stožice, spomenik prve svetovne vojne iz leta 1927 na pokopališču ob župnijski cerkvi sv. Jurija mučenika; Sora pri Medvodah, spomenik padlim vojakom v prvi svetovni vojni sredi pokopališča zahodno nad župnijsko cerkvijo sv. Štefana; Dolenja vas pri Kočevju, spomenik v njenem središču iz okrog leta 1930; Prečna pri Novem mestu, spomenik padlim v prvi svetovni vojni iz okrog leta 1930 v parku ob župnijski cerkvi sv. Antona Padovanskega; Šentviška Gora v občini Tolmin, spomenik padlim v prvi svetovni vojni v podobi kapelice iz okrog leta 1930; Žiri, spomenik padlim v prvi svetovni vojni v obliki kapelice iz leta 1938 ob farni cerkvi sv. Martina v Žireh; Rovte nad Logatcem, spomenik padlim v prvi svetovni vojni v obliki kapelice iz leta $1944 \mathrm{idr}$.

Samostojno stoječi spomeniki v neposredni bližini cerkva in župnišč ali vgrajeni na njihova pročelja: Adlešiči v Beli krajini, spominsko znamenje iz leta 1948 na vzhodnem pročelju župnijske cerkve sv. Nikolaja v spomin žrtvam prve in druge svetovne vojne; Kovor blizu Tržiča, spominsko znamenje iz leta 1926 na južnem pročelju župnišča ob cerkvi sv. Janeza Krstnika; Ribno pri Bledu, spominsko znamenje iz okrog leta 1925 na zahodnem pročelju pokopališke cerkve sv. Jakoba; Stara Loka, spomenik padlim v prvi svetovni vojni iz leta 1930 ob vzhodni steni župnijske cerkve sv. Jurija; Trebnje, spomenik padlim v prvi svetovni vojni iz leta $1933 \mathrm{ob}$ severnem uličnem pročelju župnijske cerkve Marijinega vnebovzetja idr.

$\mathrm{V}$ ostenja stavbnih pročelij vgrajena znamenja - spominske plošče: Tolmin, župnijska cerkev Marijinega vnebovzetja; Kresnice, župnijska cerkev sv. Benedikta; Solčava, župnijska cerkev sv. Marije Snežne; Podpeca, podružnična cerkev sv. Helene; Dvor pri Polhovem Gradcu, podružnična cerkev sv. Nikolaja z nišo ob vznožju zvonice s spominsko ploščo padlim vojakom v prvi svetovni vojni; Godešič, podružnična cerkev sv. Nikolaja. Spominska plošča padlim vojakom v prvi svetovni vojni, vzidana levo ob zaprtih vratih arkad v pritličju zvonice; Voklo, župnijska cerkev sv. Jerneja. Spominska plošča je vzidana v arkado pod zvonico, desno ob vhodu v cerkev; Spodnja Slivnica, podružnična cerkev sv. Petra in Pavla. Spominska plošča, vzidana pod arkado ob zvonici; Turnišče, župnijska in romarska cerkev Marije Vnebovzete. Spominska plošča, vzidana pod (sekundarno vgrajeno) lopo ob vhodu v cerkev; Brezje, romarska in župnijska cerkev Marijinega 
vnebovzetja; Pernica, župnijska cerkev sv. Marjete; Luže v občini Šenčur, kapelica; Šentvid nad Horjulom, kapelica odprtega tipa s kipom Jezusa Kristusa v niši in spominsko ploščo padlih vojakov pod njo; Stara Cerkev pri Kočevju, župnijska cerkev Marijinega vnebovzetja; Mavčiče, župnijska cerkev sv. Petra; Šmihel pri Novem mestu, kapelica na pokopališču s spominsko ploščo padlih vojakov v prvi svetovni vojni; Tolmin, župnijska cerkev Marijinega vnebovzetja z znamenjem v spomin padlih vojakov v prvi svetovni vojni iz leta 1924; Župnijska stavba ob pokopališkem zidu z vgrajenim znamenjem v spomin padlim vojakom v prvi svetovni vojni z marmornato ploščo; Spodnja Dobrava pri Kolpi, podružnična cerkev sv. Križa s spominsko ploščo padlim vojakom v prvi svetovni vojni; Brezje, romarska cerkev Marija Pomagaj ima spominsko ploščo vzidano na zunanjščino južne kapele; na vogal župnijske cerkve Jerneja apostola v Begunjah pri Cerknici vzidano spominsko znamenje padlim vojakom v prvi svetovni vojni. Globoki relief je delo kiparja Franceta Kralja; znamenje iz leta 1930 na stranski južni kapeli župnijske cerkve Marijinega rojstva v Šmarju - Sap; Kresnica, župnijska cerkev sv. Benedikta s spominsko ploščo in znamenitim posvetilnim besedilom (epitafom): »Minuli so boji minulo trpljenje, za dom svoj preljubi smo dali življenje. Zdaj širom sveta naša trupla trohne, a gor nad oblaki spet združimo se. « Postavili občani 1925; Tunjice, blagoslov spominske plošče padlim vojakom v prvi svetovni vojni, 26. julija 2014, vzidane na severno steno mrliške vežice ob pokopališču in pod župnijsko cerkvijo sv. Ane; Opatje selo, spominska plošča padlim v prvi svetovni vojni. »V sodelovanju s KS Opatje selo, občino Miren-Kostanjevica in podporo domačih podjetij Marušič d.o.o. in Gostilna Štirna, je TD Cerje uresničilo svojo pobudo « idr.

\section{IZBRANI PRIMERI SAMOSTOJNO STOJEČIH SPOMENIKOV}

Po končani prvi svetovni vojni so župnije in občine ob pomoči krajanov spomenike padlim in pogrešanim rojakom - vojakom - postavljale že v začetku dvajsetih let. Med prvimi so ga postavili v Bohinjski Beli pred cerkvijo sv. Marjete. Po načrtih arhitekta Ivana Vurnika so ga zgradili med letoma 1920 in 1922. Spomenik stoji na šeststranem betonskem podstavku, na katerega je položena kamnita plošča, nanjo pa tristrani kamniti obelisk z dvema enako oblikovanima stranicama. $\mathrm{V}$ ploščo je vklesanih dvanajst niš, $\mathrm{v}$ katerih so danes vaze $\mathrm{z}$ umetnim cvetjem. Na eni od teh plošč je zgoraj napis Iz let 1914-1918, na drugi »žrtvam kuge + lakote + vojne «, pod njima pa so priimki in 
imena ter datumi smrti vojakov. $\mathrm{Na}$ (domnevno) čelni strani, obrnjeni proti cerkvi, je napis »Postavili farani Boh. Bele «, sledijo niše z imeni vojakov, ki so padli leta 1914, in vojaka, ki je 8. oktobra 1920 (domnevno) podlegel vojnim ranam doma. Kasneje so dodali napis »Spominu vojakov jugoslav. vojske «, ki so umrli v Zaječarju (1924), Bitoli (1926) in Nišu (1929). Vrh spomenika je pritrjen kovinski ornament $s$ tremi križci.

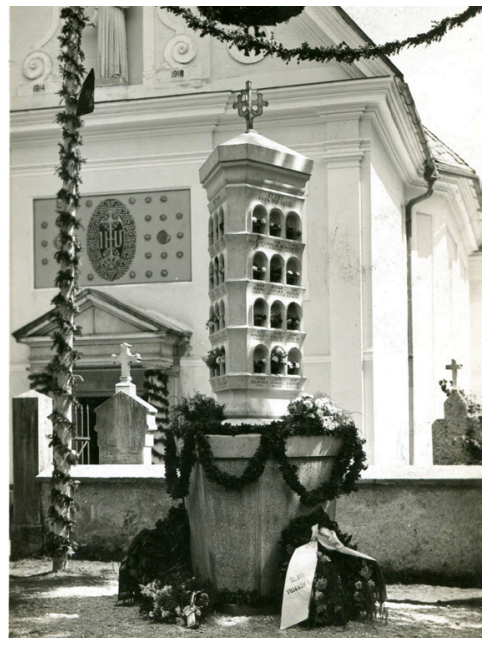

Slika 25: Bohinjska Bela, fotografija Vurnikovega spomenika ob svečanem odkritju leta 1922 pred cerkvijo sv. Marjete (foto: neznani avtor, fotografija iz arhiva Janeza Bogataja).

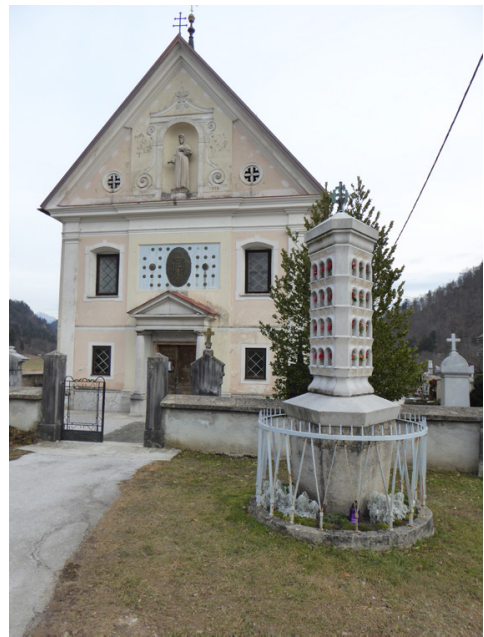

Slika 26: Bohinjska Bela, fotografija Vurnikovega spomenika leta 2019 pred cerkvijo sv. Marjete. Podoba spomenika ni bistveno drugačna, obdaja ga le nova kovinska varovalna ograja (foto: Vito Hazler, 13. 1. 2019).

Spomeniki prve svetovne vojne so pomembno zaznamovali posamezne kraje, vaške skupnosti, župnijsko in društveno življenje ter življenje posameznikov, ki so sodelovali pri njihovi izgradnji ali kot pooblaščenci skrbeli za njihovo varovanje. Virov o teh in podobnih dogodkih je sicer veliko, a le redko se pripeti, da bi bilo o katerem spomeniku na voljo toliko podatkov, kot jih poznamo o spomeniku padlim vojakom - domačinom - iz Grajske vasi v Spodnji Savinjski dolini. Tam od leta 1924 stoji skoraj $4 \mathrm{~m}$ visok spomenik, ki je povsem vraščen v središčno naselbinsko zasnovo Grajske vasi. Stoji namreč na južni strani podružnične cerkve sv. Krištofa ter skupaj s cerkvijo in okoliškimi domačijami soustvarja enega najbolj vzorčnih primerov centralno zasnovanih vasi na Slovenskem. Zdi se, da središčna zasnova vasi odseva tudi v zglednem delovanju vaške skupnosti, ki je že nekaj let po vojni izbrala odbornike za postavitev spomenika. Iz hvaležnosti za srečno vrnitev iz vojne domov in spoštovanja 
do padlih sovaščanov je vlogo predsednika in blagajnika pripravljalnega odbora prevzel posestnik Jernej Kunst, ki je vse od začetnih priprav do svečanega odkritja vodil izgradnjo spomenika. Načrt je izdelal zidarski mojster Ivan Basle (po nekaterih virih Vasle), ki si je spomenik zamislil v obliki trikotnega stebra, vrh katerega je postavil odprto tristrano lopo z betonsko streho in križem na vrhu. Modele za betonske odlitke je izdelal Martin Rajovec, v odprto trikotno lopo na vrhu pa so postavili leseni kip sv. Martina, ki ga je izdelal celjski kipar Miloš Hohnec. ${ }^{38} \mathrm{~V}$ trikotni spodnji del spomenika so vgrajene marmornate plošče, ki jih je izdelala Kamnoseška družba iz Celja. Na ploščah je trikrat deljen napis »Spomin padlim vojakom « in na vseh treh straneh 1914-1919, na vsaki strani pa so še imena treh, torej skupaj devetih padlih vojakov. Najmlajši med njimi je umrl star 21, najstarejši pa 40 let. Vaščani so spomenik pred leti temeljito obnovili in odprto tristrano lopo zaščitili s pleksisteklom. O pomenu spomenika in njegovi obnovi je bil glasilu Kulturnega društva Gomilsko objavljen članek z naslovom Grobovi tulijo ..., ki ga je napisala Marija Rančigaj (2002). V zanimivem članku, ki ima enak naslov kot prispevek, objavljen v časniku Jutro leta $1924,{ }^{39}$ je avtorica podrobno predstavila vse okoliščine nastajanja in izgradnje spomenika ter navedla številne druge vsebinske podatke, ki jih je zbrala med domačini in $\mathrm{v}$ Zgodovinskem arhivu Celje. Opisala je tudi krajo ene od treh železnih granat, ki so jih julija 1924 ulili v Jeklarni na Ravnah za 1.435 din. Odtujitev granate je okrnila pričevalnost spomenika, ustrezne nadomestne granate pa domačinom še ni uspelo pridobiti. ${ }^{40}$

Spomenik padlim vojakom v prvi svetovni vojni so le nekaj let po končani moriji postavili v Borovnici na jugozahodnem obrobju Ljubljanskega barja. Zelo členjen spomenik, morda v obliki narobe obrnjenega lectovega srca, je delo arhitekta Otona Grebenca in blogspot.com/2016/07/grajska-vas-spomenik-padlim-v-prvi.html, prevzeto 15. 9. 2018).

39 Članek je nepodpisan, a poznavalci menijo, da ga je napisal urednik in novinar Jutra Stanko Virant, sicer domačin iz Gomilskega, kjer je sedež župnije, ki ji pripada tudi cerkev sv. Krištofa v Grajski vasi (Nepodpisano 1924). V članku avtor predstavlja tudi vrsto uspešnih postavitev spomenikov prve svetovne vojne v Franciji in besedilo dopolni z več fotografijami. Objavljena je tudi fotografija pokopališča pri Sv. Križu v Ljubljani s spomenikom tako imenovanega Kranjskega Janeza še na njegovi prvotni lokaciji ob vojaških grobovih.

40 O tem je poročala Marija Rančigaj: »Pogovarjala sem se tudi z g. Milanom Sušakom, ki se je potrudil in nabavil nadomestno granato iz soške fronte, ki je sicer potrebna precejšnje prenove. Žal pa nima popolnoma enakih dimenzij, saj je izhajala iz italijanske, ne avstrijske strani, njen premer pa je za 2 cm manjši« (Rančigaj 2002: 18-19). 


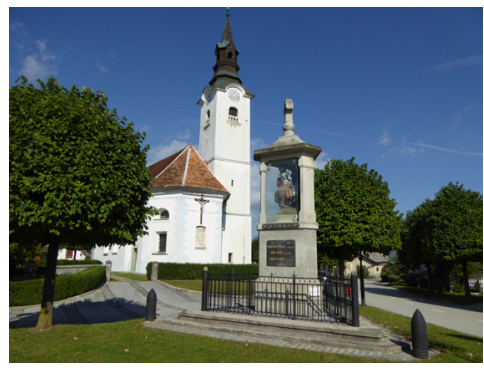

Slika 27: Grajska vas, spomenik padlim v prvi svetovni vojni iz leta 1925 pred podružnično cerkvijo sv. Krištofa (foto: Vito Hazler, 29. 9. 2018).

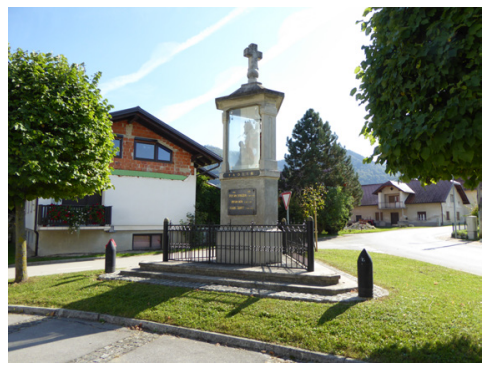

Slika 28: Grajska vas, pogled na spomenik s severne strani (foto: Vito Hazler, 29. 9. 2018).

kamnoseka Karla Novaka ${ }^{\mathbf{4 1}}$ iz Šentvida nad Ljubljano. ${ }^{\mathbf{4 2}}$ Svečano so ga odkrili leta 1926, o čemer priča vklesana letnica na njegovem podstavku. Poleg izpričanega kamnoseškega mojstrstva se malce pozornejše opazovalčevo oko ustavi na medaljonu na vrhu spomenika, ki je zasnovan v obliki navojnice, ob katero so levo, desno in zgoraj dodani trije valjčki, medtem ko so okroglemu osrednjemu polju medaljona (domnevno) ob obnovi spomenika pred leti dodali okrogel plošček z grbom občine Borovnica (sic!).

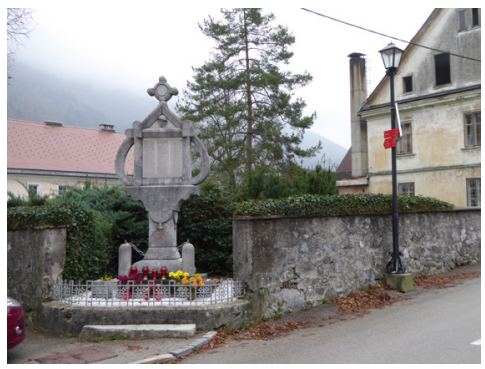

Slika 29: Borovnica, spomenik padlim vojakom v prvi svetovni vojni iz leta 1926 (foto: Vito Hazler, 5. 11. 2018).

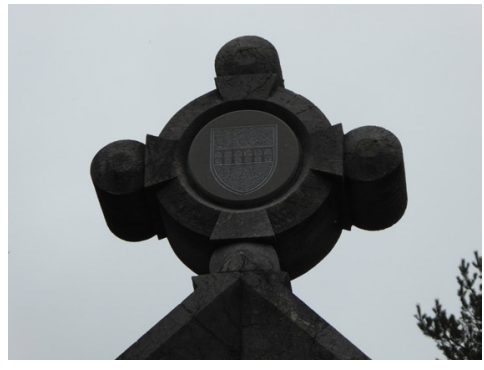

Slika 30: Borovnica, medaljon vrh spomenika padlim vojakom v prvi svetovni vojni (foto: Vito Hazler, 5. 11.2018).

Karel Novak (4. 11. 1880-1. 5. 1947) je bil izvrsten kipar. Bil je povsem gluh in v nesreči ga je povozil vlak. Njegovi pranečaki še hranijo pomemben del dokumentacije o družinski kamnoseški dejavnosti, ki je bila do konca druge svetovne vojne ena izmed številnih obrtniških dejavnosti v Šentvidu nad Ljubljano.

42 Borovnica - Spomenik padlim v prvi svetovni vojni (spletni vir: http://spomeniki. blogspot.com/2014/10/borovnica-spomenik-padlim-v-prvi.html, prevzeto 15.9 . 2018). 
Spomenike padlim vojakom so po končani svetovni vojni postavljali tudi v Prekmurju. V Martinju na Goričkem stoji tik nad regionalno cesto visok kamnit spomenik z stopničasto betonsko podlago in kamnoseško kakovostno izdelanim motivom Križanega in pod njim v nišo postavljenim kipom Matere Božje. Na čelni strani so od zgoraj navzdol naslednji napisi: Hvalen bodi Jezsus Krisztus in 1914-16, pod kipom MB pa napis: »Je postavljen ta Križ sveti / Kda so telki mogli mreti / V tom strašnom svetounom boji / Pred njim so potrta srca / Jokala tolažbo najšla / Se povrnila K svojemi Bogi.« Spomenik je zasnovan podobno kot več drugih katoliških znamenj z območja severovzhodne Slovenije in zlasti Prekmurja, kjer sta se srečevala katoliški in protestantski svet.
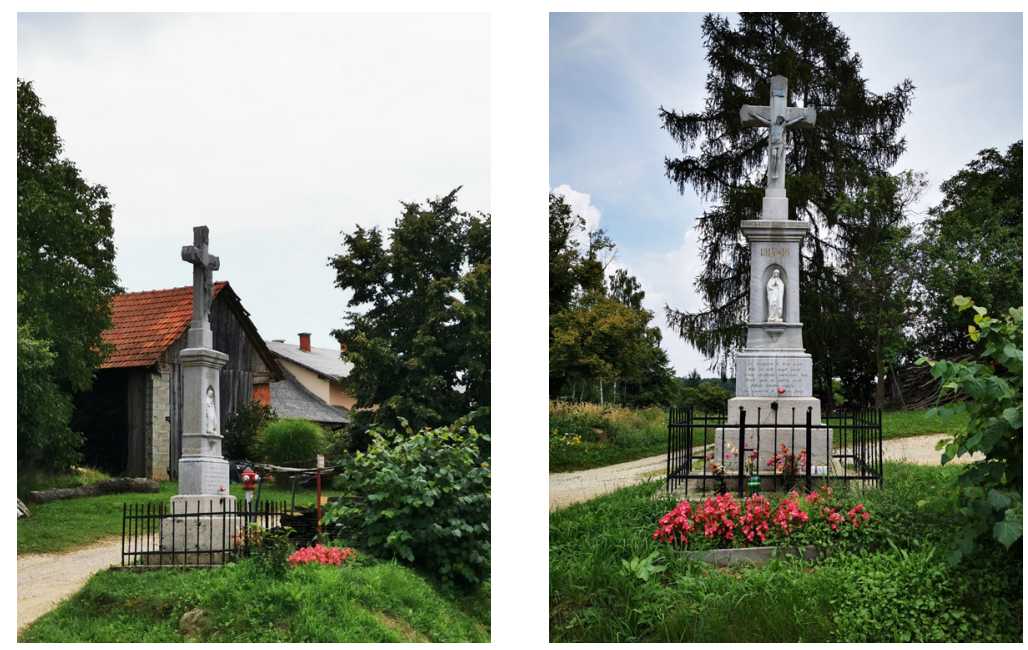

Sliki 31 in 32: Martinje na Goričkem v Prekmurju. Spomenik padlim vojakom v prvi svetovni vojni v obliki katoliškega znamenja (foto: Božidar Jezernik, 11.8.2020).

V Polju pri Ljubljani so spomenik padlim vojakom v prvi svetovni vojni postavili leta 1926. Zasnoval ga je kipar Lojze Dolinar, ki je izdelal 2,3 m visok kip vojaka in $2 \mathrm{~m}$ visok pravokotniški podstavek. Sprva je za spomenikom stala ljudska šola, ki so jo pozneje podrli, tam uredili park in razširili pokopališče. Dolinarjev spomenik že leta vzbuja dvome o izvirnosti podobe avstro-ogrskega vojaka, saj nekatere spominja na francoskega vojaka tistega časa. Izvirno oblikovane so tudi črke besedil in seznamov padlih vojakov. Posebej izstopa črka E, ki je upodobljena v obliki grške črke sigma. Na spomeniku so poleg vodilnega napisa »Žrtvam svetovne vojne « napisani tudi priimki in imena 97 padlih vojakov iz naslednjih krajev: Devica Marija v Polju (9), Vevče (15), Studenec (8), Fužine (6), Slape (9), Spodnja Zadobrova (4), 
Zgornja Zadobrova (5), Sneberje (12), Zgornji Kašelj (14), Spodnji Kašelj (6) in Zalog (9).

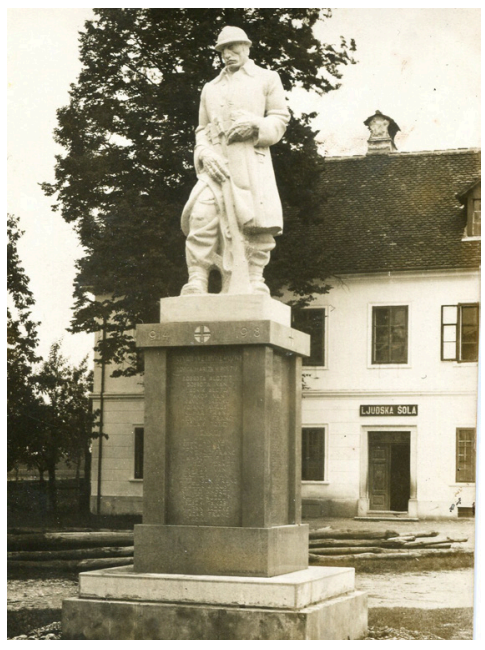

Slika 33: Polje pri Ljubljani, spomenik padlim vojakom v prvi svetovni vojni iz leta 1926 pred nekdanjo ljudsko šolo (foto: neznani avtor, okrog 1930, fotografija iz arhiva Janeza Bogataja).

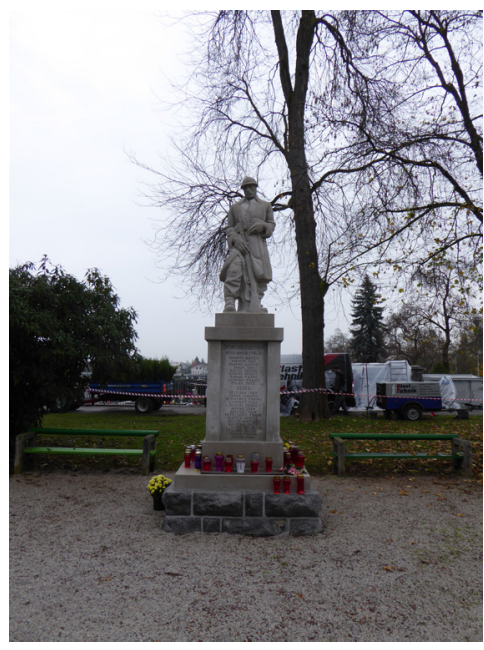

Slika 34: Polje pri Ljubljani, spomenik padlim $\mathrm{v}$ prvi svetovni vojni sredi parkovno urejene okolice (foto: Vito Hazler, 5. 11. 2018).

V Črnučah pri Ljubljani stoji spomenik padlim v prvi svetovni vojni pred župnijsko cerkvijo sv. Simona in Juda Tadeja. Leta 1927 so ga postavili po načrtih arhitekta Ivana Vurnika (1927). Zasnovan je v obliki kretskega stebra z močnim valjastim kapitelom in jonskimi valovnicami z dodanimi križci na vrhu. ${ }^{\mathbf{4 3}}$ Pod kapitel je vgrajen kovinski obroč s štirimi laternami, pod njim je na stebru uokvirjen napis $\gg \check{Z} r$ tvam kuge in lakote iz let 1914-1918«. Na treh straneh razširjenega kapitela je navedenih 34 priimkov in imen ter letnice rojstva in smrti padlih vojakov iz vasi Črnuče, Gmajna, Prod, Nadgorica, Podboršt, Dobrova in Ježa. Najmlajši med padlimi je bil star 19, najstarejši pa 40 let. Prvotna zasnova spomenika je bila likovno in prostorsko mnogo popolnejša, kot je danes. Prvotno je spomenik obdajal dvojni betonski obroč, ki je obdajal gredico z zasajenim cvetjem. Na zunanji betonski obroč so bile vgrajene kovinske palice za okrasno verigo. Danes je okrog spomenika le nizek betonski krog s kamnitimi tlakovci, zalitimi $\mathrm{v}$ beton. Tudi okolica pred cerkvijo ima preveč nasutih zemljin. 


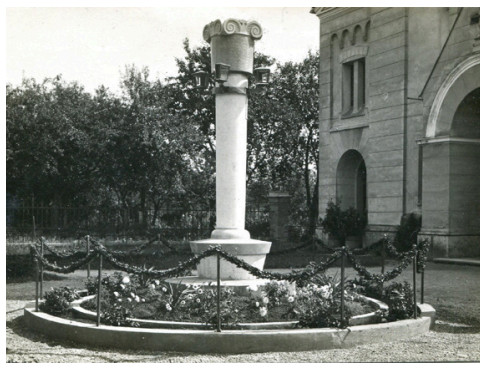

Slika 35: Črnuče pri Ljubljani, spomenik padlim vojakom v prvi svetovni vojni pred cerkvijo sv. Simona in Juda Tadeja okrog leta 1927 (foto: neznani avtor, fotografija iz arhiva Janeza Bogataja).

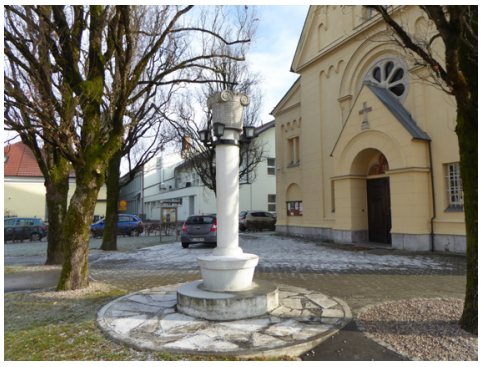

Slika 36: Črnuče pri Ljubljani, spomenik padlim vojakom v prvi svetovni vojni pred cerkvijo sv. Simona in Juda Tadeja leta 2019. Podoba spomenika je močno razvrednotena, saj so odstranjene bistvene sestavine njegovega neposrednega kompozicijskega tkiva (foto: Vito Hazler, 9. 1. 2019).

V Srednji vasi v Bohinju je na griču severno nad vasjo župnijska cerkev sv. Martina s pokopališčem. Blizu kamnitih stopnic, ki so od cerkve speljane proti vasi, je na južni pokopališki zid prislonjen več kot $3 \mathrm{~m}$ visok spomenik, postavljen $\mathrm{v}$ spomin padlim avstro-ogrskim vojakom v prvi svetovni vojni. Spomenik so domnevno leta 1927 zgradili po načrtih arhitekta Ivana Vurnika, kar navaja spletni vir Ivan Vurnik - Pogled osebnosti, oziroma leta 1929, kar navaja spomeniškovarstveni vir. ${ }^{44}$ Vgrajen je v pokopališki zid in med dve slopni znamenji s štirikapnima strešicama. Zasnovan je kot visoka in vitka kapelica z razmeroma nizko strešico. V zadnjo steno niše je vzidana visoka marmornata plošča iz dveh delov, na kateri je vpisanih 82 priimkov in imen vojakov, kraj in hišna številka ter leto rojstva in smrti. Padli vojaki so bili doma iz Srednje vasi, Stare Fužine, Češnjice, Studora, Jereke, Podjelja, Polja in Laškega Rovta. Med navedenimi vojaki so tudi bratje iz štirih družin, ki so, kot kaže, v vojni izgubile po dva družinska člana. Na levi strani je na ozki fasadi vpisano posvetilo »Žrtvam svetovne vojne 1914-1918, farani «. Spomenik je delo kamnoseka Alojza Vurnika iz Radovljice. ${ }^{45}$

V Stari Loki so leta 1930 ob vzhodno steno župnijske cerkve sv. Jurija postavili spomenik, ki je takrat veljal za največji postavljeni spomenik padlim vojakom v prvi svetovni vojni v Dravski banovini Kraljevine Jugoslavije. ${ }^{\mathbf{4 6}}$ Kip vojaka in relief Matere Dolorose je izdelal

Seznam dediščine prve svetovne vojne, vključene $\mathrm{v}$ register nepremične kulturne dediščine (spletni vir: http://www.potmiru.si/unesco/Seznam_vojaskih_pokopalisc_ in_kostnic_2017.pdf, prevzeto 4.12.2018). spomeniki/122, prevzeto 29. 9. 2018). 


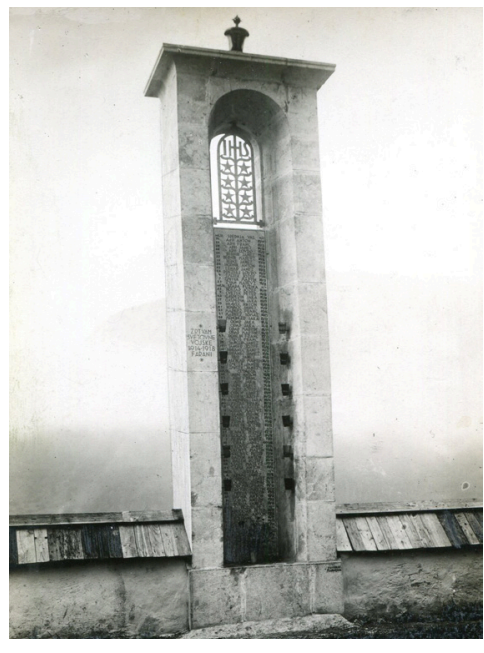

Slika 37: Srednja vas v Bohinju, spomenik padlim v prvi svetovni vojni na posnetku po letu 1927 (foto: neznani avtor, iz arhiva Janeza Bogataja).

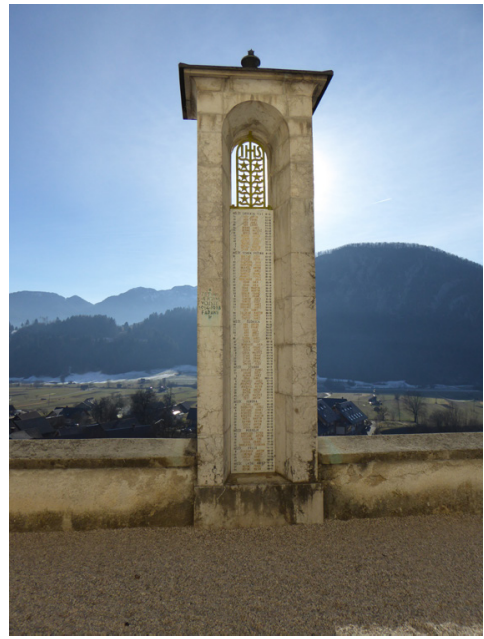

Slika 38: Srednja vas v Bohinju, spomenik padlim v prvi svetovni vojni ima danes nekoliko okrnjeno podobo, saj manjka 12 konzol z vrčki - za cvetje ali sveče? (foto: Vito Hazler, 13. 1. 2019).

komaj dvajsetletni kipar Božo Pengov (1910-1985), vsa ostala kamnoseška dela pa so opravili kamnoseki podjetnika Alojza Vodnika iz Ljubljane. Dekanijska cerkev je poklonila monumentalni nagrobnik bankirja Heissa, ki so ga uporabili za podstavek. Spomenik so slovesno odkrili 26. oktobra $1930 .{ }^{47}$ Umeščen je v zidni zalom (nišo cerkve) in je s čelne strani zaprt $s$ kovinsko ograjo. Sestavljajo ga podstavek in več plasti likovno razgibanih blokov, ki se ožijo do podesta spomenika, stoječega na $\mathrm{z}$ valovnicama okrašenem kvadru, v katerega je na čelni strani vgrajen relief Matere Dolorose iz belega kamna. Vojak je oblečen v nemško vojaško uniformo in ima rahlo upognjena kolena. $\mathrm{Z}$ desnico se opira na puško, z levico pa se dotika puškine cevi. Pod Marijinem reliefom je na plastovito čelno stran vgrajena marmornata plošča s priimki in imeni padlih vojakov iz Škofje Loke in okoliških vasi. V štirih kotih ob napisu sta dodani letnici 1914 in 1918. Spodnji podstavek spomenika je okrašen s prekrižanima in navzdol obrnjenima plamenicama. 


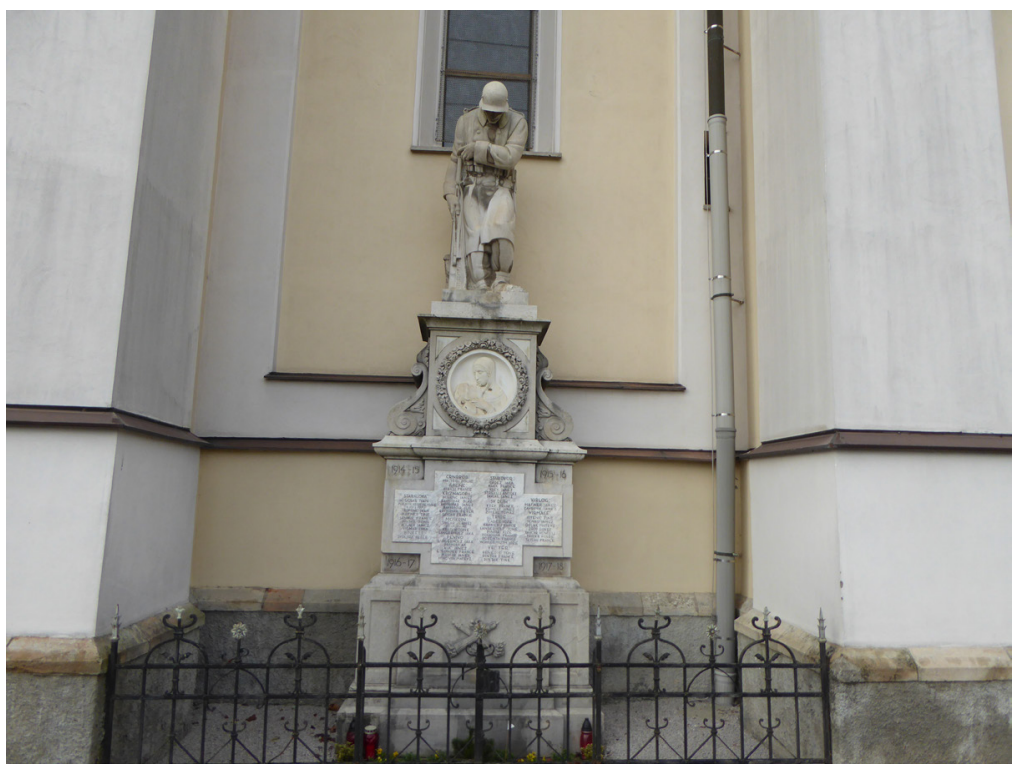

Slika 39: Stara Loka, spomenik padlim vojakom v prvi svetovni vojni ob vzhodni steni župnijske in pokopališke cerkve sv. Jurija (foto: Vito Hazler, 10. 12. 2018).

V večini primerov so spominske plošče - znamenja - vgrajevali na vidna mesta na pročeljih cerkva (na primer Tolmin, župnijska cerkev Marijinega vnebovzetja; Kresnice, župnijska cerkev sv. Benedikta), ponekod tudi manj vpadljivo ob vznožja pročelij (na primer Solčava, župnijska cerkev sv. Marije Snežne; Podpeca, podružnična cerkev sv. Helene), v niše pri tleh v zvonicah (na primer Dvor pri Polhovem Gradcu, podružnična cerkev sv. Nikolaja), v arkade pod zvonicami (na primer Godešič, podružnična cerkev sv. Nikolaja; Voklo, župnijska cerkev sv. Jerneja) ali ob njih (na primer Spodnja Slivnica, podružnična cerkev sv. Petra in Pavla), pod (sekundarno vgrajeno) lopo ob vhodu v cerkev (na primer Turnišče, župnijska in romarska cerkev Marije Vnebovzete), v notranjščine cerkva (na primer Boštanj, župnijska cerkev Povišanja svetega križa; Brezje, romarska in župnijska cerkev Marijinega vnebovzetja; Pernica, župnijska cerkev sv. Marjete) ter na zunanjščine (na primer Luže v občini Šenčur, kapelica ${ }^{48} \mathrm{v}$ križišču in središču vasi) in notranjščine (na primer Šentvid nad Horjulom, kapelica odprtega

V Lužah kapelica s kipom Matere Božje z detetom v niši stoji sredi križišča in je obrnjena proti jugu. Nad nišo je vgrajena spominska plošča iz črnega marmorja z osmimi priimki in imeni, $z$ datumi rojstva in smrti teh vojakov ter dveh pogrešanih vojakov, pri katerih pa je navedeno le leto rojstva. Na plošči je napis »1914-1918 v spomin žrtvam svetovne vojne iz Luž«. Desno spodaj je dodan kamnosek Lovec Mengeš. 
tipa s kipom Jezusa Kristusa v niši in spominsko ploščo padlih vojakov pod njo) že obstoječih kapelic.
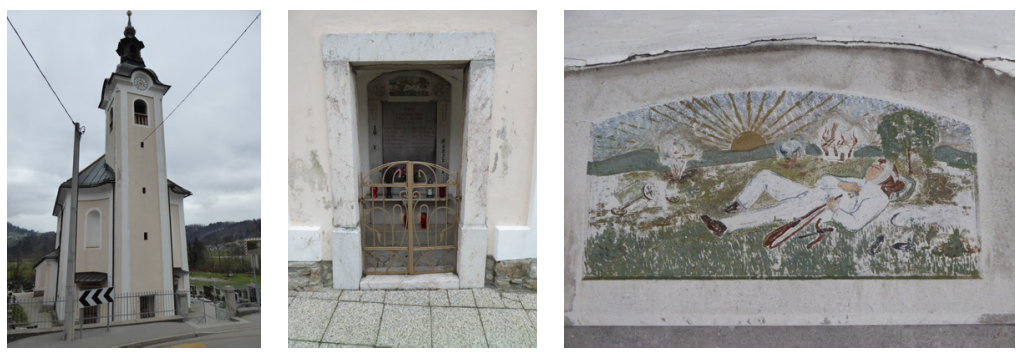

Slike 40, 41 in 42: Dvor pri Polhovem Gradcu, podružnična cerkev sv. Nikolaja z nišo ob vznožju zvonice s spominsko ploščo padlim vojakom v prvi svetovni vojni. Napisi na plošči zgoraj »V spomin v svetovni vojni padlim vojakom《in spodaj »Spominski kamen ta naj oznanjuje smrt njih, ki krije prst jih zemlje tuje «. Kamen so postavili »tovariši in rojaki«.
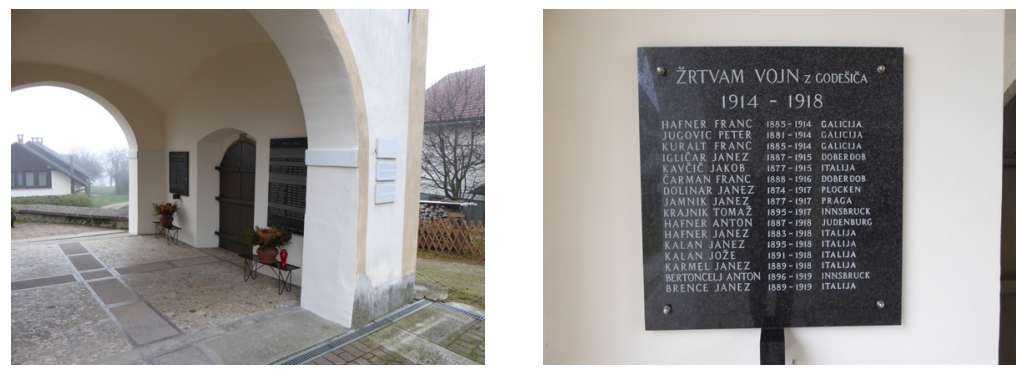

Sliki 43 in 44: Godešič, podružnična cerkev sv. Nikolaja. Spominska plošča padlim vojakom v prvi svetovni vojni, vzidana levo ob zaprtih vratih arkad v pritličju zvonice (foto: Vito Hazler, 10. 12. 2018).

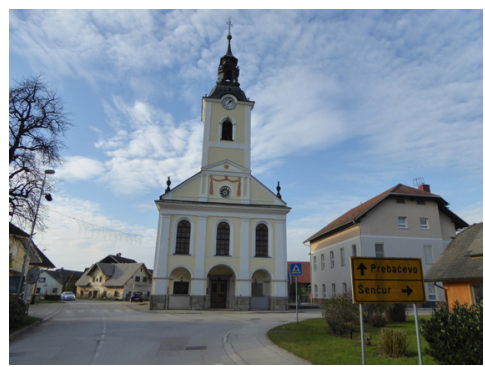

Slika 45: Voklo, župnijska cerkev sv. Jerneja. Spominska plošča je vzidana $\mathrm{v}$ arkado pod zvonico, desno ob vhodu v cerkev (foto: Vito Hazler, 1. 12. 2018).

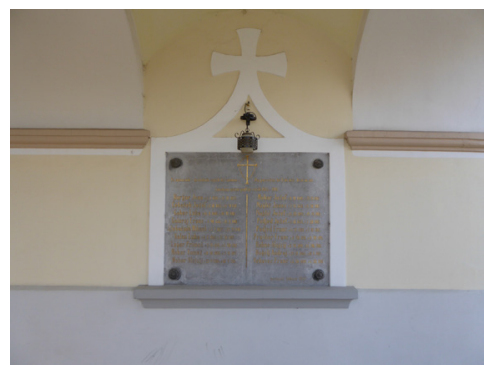

Slika 46: Voklo, župnijska cerkev sv. Jerneja. Spominska plošča v spomin padlim vojakom v prvi svetovni vojni (foto: Vito Hazler, 1. 12. 2018). 


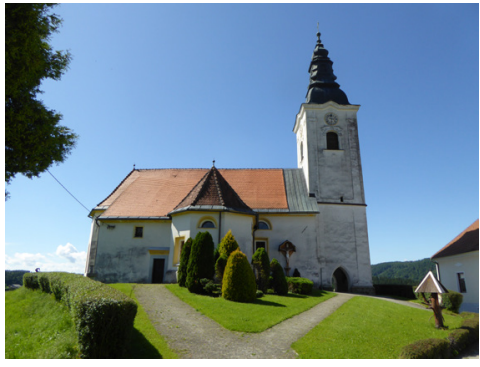

Slika 47: Arnače, župnijska cerkev sv. Ilja. V arkadno lopo pod zvonikom je na njeno zahodno steno vzidana spominska plošča padlim vojakom - domačinom $\mathrm{v}$ prvi svetovni vojni (foto: Vito Hazler, 11.6.2020).

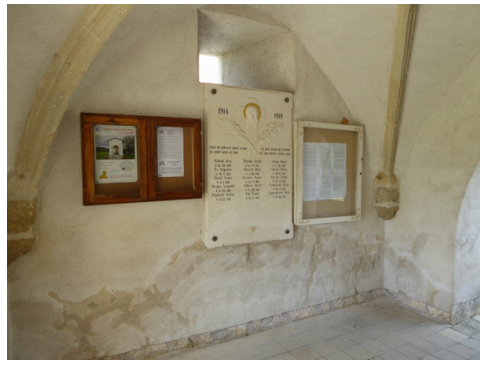

Slika 48: Arnače, župnijska cerkev sv. Tilna. Med letnicama 1914-1919 je relief glave kronanega Kristusa, pod njim pa $\mathrm{v}$ beli marmor vklesana napisa $\gg$ Kdor se bori kot zvest vojak do smrti, meni je enak « in »Ob moji strani mu pripravi moj oče mesto $\mathrm{v}$ večni slavi«. Pod napisom so po abecednem vrstnem redu vklesana imena padlih vojakov in datumi njihove smrti (foto: Vito Hazler, 11.6.2020).

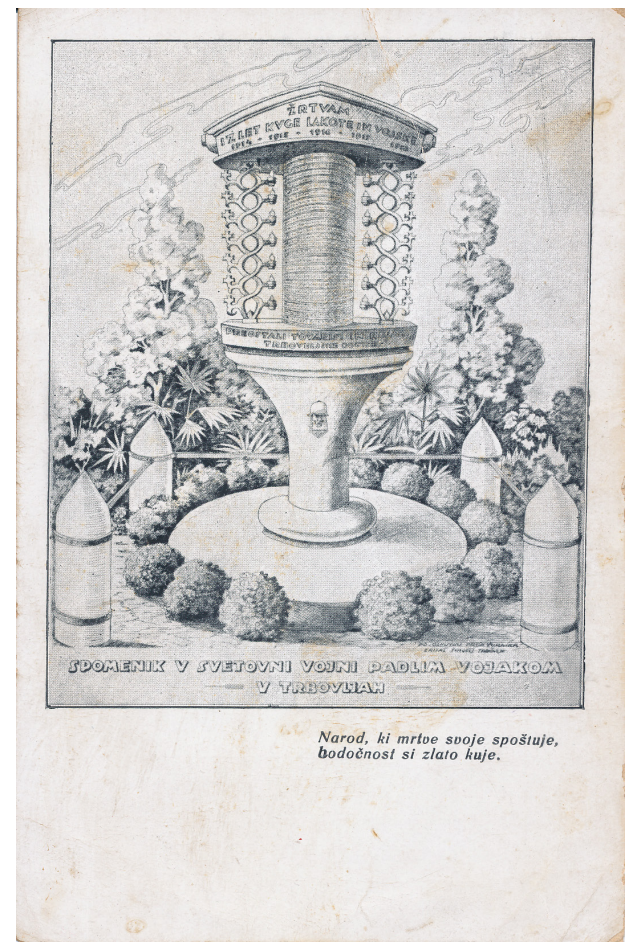

Slika 49: Trbovlje, spomenik padlim v prvi svetovni vojni, delo arhitekta Ivana Vurnika iz leta 1927. Spomenik so med drugo svetovno vojno podrli nemški okupatorji (foto: neznani avtor, razglednica iz zbirke Božidarja Jezernika). 


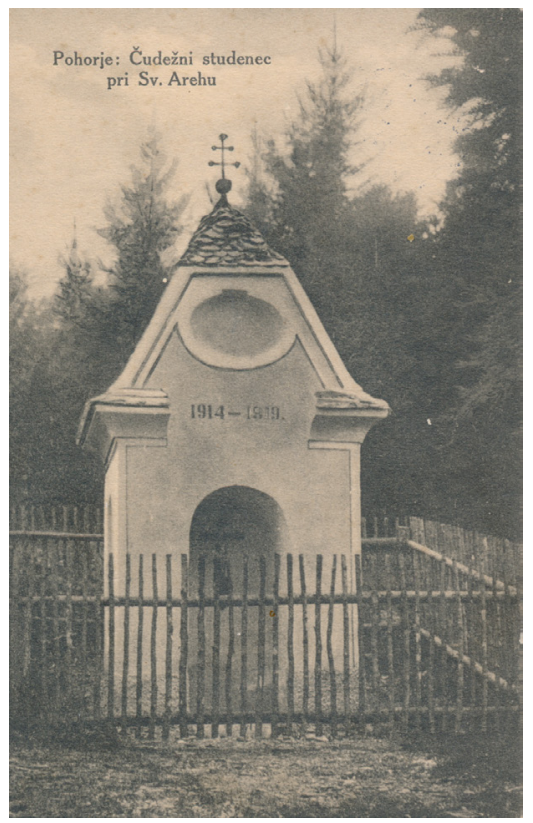

Slika 50: Poštna razglednica kapele s čudežnim studencem pri podružnični cerkvi sv. Areha na Pohorju. Na pročelju sta nad vhodnim lokom in pod ovalno stensko nišo vpisani letnici 1914-1919 (vir: razglednica iz zbirke Božidarja Jezernika).

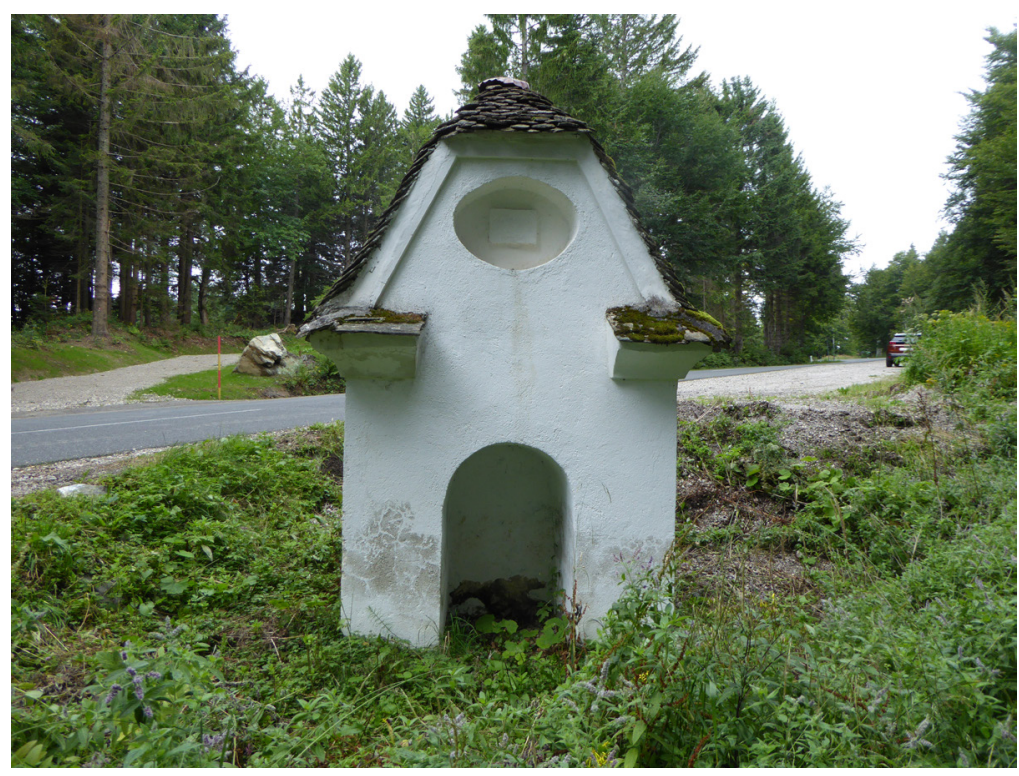

Slika 51: Današnja podoba kapelice ob cesti pod Ruško kočo in cerkvijo sv. Areha je le še bled spomin na nekdaj zgledno oskrbovano obcestno znamenje in čudežnim studencem pod njim, kjer voda ne teče več. Zaradi občutno dvignjene ravni nove ceste se kapelica dobesedno pogreza v močno zaraščeno zemljišče (foto: Vito Hazler, 2.9.2020) 
Dediščina vojaških pokopališč, kapelic, spomenikov in spominskih znamenj prve svetovne vojne je zelo obsežna, zato v pričujočem besedilu ni bilo mogoče obravnavati niti večine zbranih podatkov. Izbor je zgolj informativen ter morda spodbuda drugim raziskovalcem in raziskovalnim ustanovam, da gradivo topografsko obravnavajo ter ga javnosti predstavijo $\mathrm{v}$ celotnem obsegu in iz različnih zornih kotov. $S$ tem bomo dobili celovitejši in bolj celosten pregled pomembnega dela naše kulturne dediščine, ki je bil doslej bolj ali manj odrinjen od jedrnega raziskovalnega in strokovnega delovanja. $S$ temi vprašanji se varstvene ustanove ukvarjajo bolj kot ne sporadično, zato so podatki o tej vrsti kulturne dediščine metodično in metodološko dokaj neuravnoteženi. Tako je poziv $\mathrm{k}$ bolj sistematičnemu raziskovanju dediščine prve svetovne vojne zagotovo upravičen, saj je Slovenija med redkimi evropskimi državami, ki takšnih pregledov še nima.

\section{CITIRANE REFERENCE}

Avsenak, Vinko 2006 Mošeja v Logu pod Mangartom; Na fronti, revija za vojaško zgodovino, št. 4, str. 45-50.

BAUER, E. 1985 Der Lowe vom Isonzo, Feldmarschall Svetozar Boroeviæ de Bojna. Graz: Styria.

BenEDik, VALENTIN 1984 Moravče - Restavriranje spomenika padlim v 1. svetovni vojni; Varstvo spomenikov, št. 26, str. 333.

BUdNA-KodriČ, NATAŠA 1999 Vojaki š škofjeloškega v prvi svetovni vojni. Škofja Loka: Knjižnica Ivana Tavčarja, Muzejsko društvo Škofja Loka.

Fortunat ČERnilogar, Damjana 1994 Materialni ostanki soške fronte na Tolminskem; Kronika, št. 1, str. 59-63.

ČopIČ, ŠPELCA 1958 Kipar Lojze Dolinar; Naša sodobnost, št. 8-9, str. 841-846.

1985. Lojze Dolinar. Študija in dokumentacija. Ljubljana: Slovenska akademija znanosti in umetnosti, Partizanska knjiga.

1986 Slovensko kiparstvo v času ekspresionizma in nove stvarnosti; Ekspresionizem in nova stvarnost na Slovenskem 1920-1930, str. 87-100. Ljubljana: Moderna galerija.

1987 Slovenski spomeniki padlim v prvi svetovni vojni; Kronika, št. 3, str. 168-177.

1991 Ljubljansko kiparstvo na prostem. Ljubljana: Državna založba Slovenije 1991. 
Eržen Podlipnik, Elizabeta, Mira Hodnik, Marija Kos, Teja Krašovec, Marko Mugerli, Barbara Pešak Mikec, Judita Šega, Lilijana ViDRIH LAVRENČIČ, BARBARA ŽABOTA $2015 \mathrm{~V}$ zaledju soške fronte. Elektronska izdaja 1.0. Spletni vir: http://www2.sistory.si/publikacije/razstave/V_zaledju_soske_fronte/ch06.html, prevzeto 12.6.2019.

GlobočNIK, DAmIR 2018 Spomenika padlim v 1. svetovni vojni v Škofji Loki in Stari Loki. Spletni vir: https://www.dlib.si/stream/URN:NBN:SI:DOC-G07PCK1P/ d57ef0fa-9cae-476d-82ce-d1b3223b4060/PDF, prevzeto 17. 10. 2018.

Granta, R. G. 2014 1. svetovna vojna. Veliki ilustrirani vodnik. Ljubljana: Mladinska knjiga.

Hernja Masten, Marija 2005 Prva svetovna vojna, skoraj pozabljena tragedija 20. stoletja; Ljubica Šuligoj, ur. Slovenstvo na Ptujskem v 20. stoletju, str. 118-137. Ptuj: Območno združenje borcev in udeležencev NOB.

HUMAR, DARIJ 1985 Bate; Varstvo spomenikov, št. 27, str. 354.

1986 Grgarske Ravne; Varstvo spomenikov, št. 28, str. 343.

1987 Nova vas; Varstvo spomenikov, št. 29, str. 354-355.

1989 Vogršček; Varstvo spomenikov, št. 31, str. 349-350.

1991 Libušnje; Varstvo spomenikov, št. 33, str. 330-331.

1998 Avče pri Kanalu, spomenik iz 1. svetovne vojne; Varstvo spomenikov, št. 37 , str. 10.

JEZERNIK, BožIDAR 2014 Mesto brez spomina. Ljubljana: Modrijan.

Jugoslovanski SPOMENiKi, POVEZANi S 1. SVETovno vojno (1918-1941) 2018 SIMPOZIJ. Ljubljana, 18. in 19. oktober 2018. Spletni vir: http://www.igorzabel.org/30ta-zlozenka-a5_slo-fin.pdf, prevzeto 17.10. 2018.

KAČ, MAJA, UR. 2017 Pa zbogom, junaki ... Vojni dnevnik Filipa Jankoviča. Ljubljana: RTV Slovenija.

Klasič, Petra 2014 Vihar grozan, vihar strašan ... Naj čas ne zabriše spomina in grmovje ne preraste poslednjih počivališč ... (Po pripovedovanju Janka Razpeta iz Bukovega). Osnovna šola Cerkno. Raziskovalno delo učencev OŠ Cerkno ob bližajoči se 100. obletnici začetka 1. svetovne vojne; Ukopditi. Informator občine Cerkno, št. 19, str. 7-8. Spletni vir: http://www.cerkno.si/wp-content/uploads/2016/01/Ukopditi_2014_st19_april.pdf, prevzeto 11.10.2018.

Košir, Tone, Alojz Demšar in Petra leben Seljak 2013 Dediščina župnije Šentjošt. Ljudje, domačije in znamenitosti. Šentjošt: Založnik: Župnija.

LOG POD MANGARTOM 2018 Džamija. Spletni vir: http://www.logpodmangartom.si/ dzamija.pdf, prevzeto 19.9. 2018.

Mekanović, HuSEIn SejKo 2019 Bošnjaki. Spletni vir: www.bosnjak.si, prevzeto 11. 10. 2018 (na tem spletnem mestu je dostopna tudi publikacija o džamiji v Logu pod Mangartom, katere avtor je).

Luskovič, TonČEx 2009 Kog: krajepis in zgodovinopis. Velenje: Pozoj.

MASELJ, Brane 2019 Slika, ki je postala nacionalna ikona. Brezje z umetnostnim zgodovinarjem Damirjem Globočnikom; NeDelo, 7. junija, str. 28-29. 
Miler, Matija 2018 Plečnik in Koroška. Spletni vir: http://www.matijamiler.net/ plecnik.pdf, prevzeto 31. 12. 2018.

MORIC, ANJA, UR. 2018 Spomeniki prve svetovne vojne. Raziskovalna naloga študentov pri predmetu Socialni spomin in kulturna dedišcina. Univerza v Ljubljani. Filozofska fakulteta. Oddelek za etnologijo in kulturno antropologijo. Spletni vir: http:// etnologija.etnoinfolab.org/dokumenti/77/2/2018/Spomeniki_padlim_v_ prvi_svetovni_vojni_Oddelek_za_etnologijo_3294.pdf, prevzeto 26.12. 2018.

NEPODPISANo 1924 Grobovi tulijo ...; Jutro, 1. novembra, str. 5-6.

Pivka - Grobnica iz prVe svetovne vojne 2019 Spletni vir: http://spomeniki. blogspot.com/2017/05/pivka-grobnica-iz-prve-svetovne-vojne.html, prevzeto 22. 6. 2019).

Portal Arzenal 2018 Spomeniki 1. svetovne vojne. Filozofski inštitut ZRC SAZU in Zgodovinski inštitut Milka Kosa ZRC SAZU. Spletni vir: http://www.arzenal.si/sobe/zbirke/spomeniki, prevzeto 26. 9. 2018.

RESNiK, DAMJAN 2004 Soška fronta kot pomnik in muzejsko vprašanje. Ljubljana: Diplomsko delo na Fakulteti za družbene vede Univerze v Ljubljani. Spletni vir: http://dk.fdv.uni-lj.si/dela/Resnik-Damjan.PDF, prevzeto 14. 12. 2018.

PrAŠNIČKI, MARTIN 2005 Velika vojna in Barbarčani; Martin Prašnički, ur. Cirkulane, svet Belanov, str. 147-155. Cirkulane: Halo.

2014 Vojni luzerji 1914-1918. Usoda slovenskih mož in fantov. Spominsko-dokumentarna zgodba o slovenskih vojakih 87. pešpolka - IR.87. Zgornja Polskava: Samozaložba.

Prašnički, Martin, Mira Petrovič, Franc Tetičkovič in Janez Jurgec 2013 Žrtve svetovnih vojn z območja Cirkulan. Kritična analiza dogodkov, revizija in dopolnitve seznamov. Cirkulane: Društvo za oživitev gradu Borl.

Rahten, AndRej 2014 Prestolonaslednikova smrt. Ljubljana: Cankarjeva založba.

RAKUŠA, JožE 2002 Napoti je bil pri urejanju okolja cerkve. Pri Sv. Tomažu odstranjeni spomenik na ponovno postavitev čaka že deset let; Večer, 19. novembra, str. 16.

RANČIgAJ, MARIJA 2002 Grobovi tulijo ...; Detel'ca, št. 5, str. 17-19.

SimiČ, MAR Ko 1996 Po sledeh soške fronte. Ljubljana: Mladinska knjiga.

SMOLE, EMIL 1982 Javorca, Tolmin - spominska cerkev iz I. sv. vojne; Varstvo spomenikov, št. 24, str. 235.

SvoljŠAK, Petra, In Gregor ANtoličič 2018 Leta strahote. Slovenci in prva svetovna vojna. Ljubljana: Cankarjeva založba.

ŠEGA, JUdITA, UR. 2015 V zaledju soške fronte. Katalog razstave. Ljubljana: Pokrajinski arhiv Koper; Pokrajinski arhiv v Novi Gorici; Zgodovinski arhiv Ljubljana; Gornjesavski muzej Jesenice: Tolminski muzej.

ŠKodiČ, DušAN 2016. Smrt na Erzherzog Eugen Strasse. Stoletnica vršiške ceste; Planinski vestnik, št. 3 , str. 4-9.

ŠTEPEC, MARKo 2016 »Bedna kritja pod planoto tik nad Sočo«. V strelskih jarkih soškega bojišča 1915-1917. 100. obletnica prve svetovne vojne in soške fronte; Zgodovina $v$ šoli 1-2, str. 29-38. Spletni vir https://www.os-sl-mesto.si/ 
moodle/pluginfile.php/15693/mod_resource/content/1/zvs-2016-1-2-clanek-markostepec.pdf, prevzeto 13.6. 2019.

Travner, Vladimir 1936 Pokopališča v Mariboru; Kronika slovenskih mest, št. 3, str. 215-218.

Turk, Mitja 2013 Po sledeh preteklosti, Gore nad Tolminom; Planinski vestnik, št. 2, str. 29-31.

VIHAR GROZAN, VIHAR STRAŠAN ... 2018 Naj čas ne zabriše spomina in grmovje ne preraste poslednjih počivališč ... Osnovna šola Cerkno: Raziskovalno delo učencev OŠ Cerkno ob bližajoči se 100 . obletnici začetka 1. svetovne vojne. Spletni vir http://www.cerkno.si/wp- content/uploads/2016/01/Ukopditi_2014_st19_ april.pdf, prevzeto 2. 11. 2018.

VOLČJAK, JURE, UR. 2017 Vodnik po arhivskem gradivu 1. svetovne vojne. Spletni vir: http://www.arhiv.gov.si/fileadmin/arhiv.gov.si/pageuploads/publikacije/2018/Vodnik_po_ar._gr._1.pdf, prevzeto 1.1.2019.

VoJnović, ANA 2008 Integracija muslimanske verske manjšine v Sloveniji. Ljubljana: Fakulteta za družbene vede (diplomsko delo). Spletni vir: http://dk.fdv.uni-lj.si/diplomska/pdfs/vojnovic-ana.pdf, prevzeto 19. 10. 2018.

VURNiK, IVAN 1927 Pogled osebnosti - Likovna umetnost v prostoru mesta. Črnuče, spomenik padlim v prvi svetovni vojni- (spletni vir: http://www.mariborart. si/osebnost/-/article-display/ivan-vurnik, prevzeto 3. 2. 2019).

ŽEBovec, MARJETA 2014 Bojevnik: spomini vojnih veteranov prve svetovne vojne. Ljubljana: Založba Karantanija.

ŽELEZNıKI 2018 Železniki, ž. c. sv. Frančiška Ksaverija, spominska plošča padlim v 1. svetovni vojni, 2. 11. 2018: Spletni vir: http://www.obcestvo.si/aktualno, prevzeto 18. 12. 2018.

ŽUŽEK, ALEš 2018 Pozabljeni mrtvi slovenski fantje; Reporter, 22. oktobra, str. 52-55. 